\title{
Coal Resources of
}

Trinidad-Aguilar Area

Las Animas and Huerfano Counties, Colorado

GEOLOGICAL SURVEY BULLETIN 1072 -G

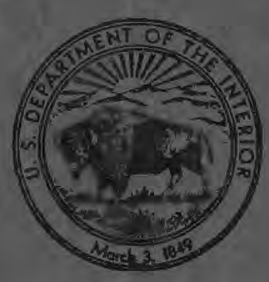


ris.

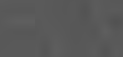

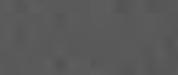

(5)
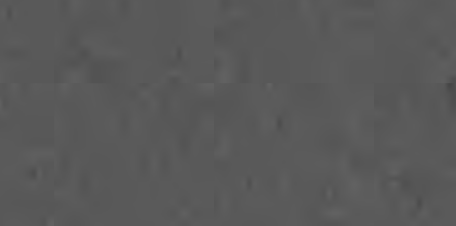

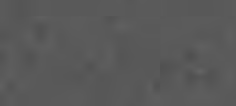

+

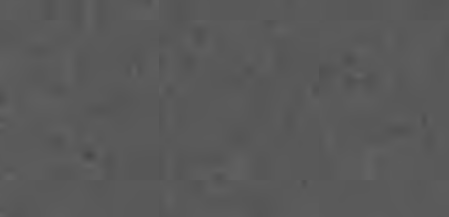




\section{Coal Resources of}

Trinidad-Aguilar Area Las Animas and Huerfano Counties, Colorado

By R. L. HARBOUR and G. H. DIXON

CONTRIBUTIONS TO ECONOMIC GEOLOGY

G E O LOG I C AL S U R VEY B U LLE T I N $1072-\mathrm{G}$

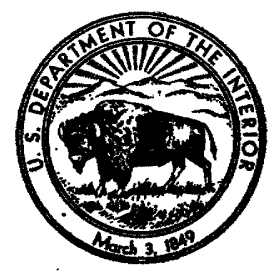




\title{
UNITED STATES DEPARTMENT OF THE INTERIOR
}

FRED A. SEATON, Secretary

\author{
GEOLOGIGAL SURVEY
}

Thomas B. Nolan, Director

For sale by the Superintendent of Documents, U.S. Government Printing Office Washington 25, D.C. - Price (paper cover) 


\section{CONTENTS}

Abstract

Page

Location and extent of the area.

Previous publications. . .

Fieldwork . . . .

Geography

Stratigraphy

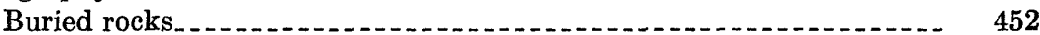

Exposed rocks. . .

Cretaceous system

Carlile shale.

Fort Hays limestone member of the Niobrara formation.... $\quad 454$

Pierre shale and Niobrara formation, undivided......... 454

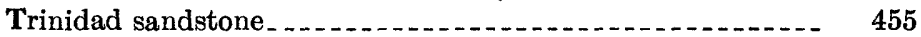

Vermejo formation

Tertiary system

Raton formation . .

Poison Canyon formation

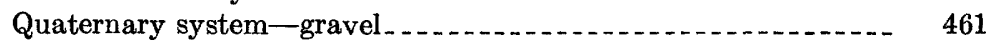

Igneous rocks.

Geologic structure

Geologic history

Oil and gas possibilities.... 468

Coal _.

Occurrence and distribution

Physical and chemical properties. 171

Development. . .

Reserves_. .

References

Index 


\section{ILLUSTRATIONS}

[Plates in separate volume]

Plate 10. Geologic map of the Trinidad-Aguilar area.

11. Generalized stratigraphic sections of the Trinidad, Vermejo, and Raton formations.

12. Sections of coal beds in Vermejo formation.

13. Sections of coal beds in Raton formation from Four Mile Canyon to Colorado Canyon.

14. Sections of coal beds in Raton formation from Smith Canyon to Cottonwood Canyon.

Figurs 17. Index map of the Raton Mesa coal region and the area of this Page report. 


\title{
CONTRIBUTIONS TO ECONOMICIGEOLOGY
}

\section{GEOLOGY AND COAL RESOURCES OF THE TRINIDAD- AGUILAR AREA, LAS ANIMAS AND HUERFANO COUN- TIES, COLORADO}

\author{
By R. L. Harbour and G. H. Dixon
}

\begin{abstract}
The Trinidad-Aguilar part of the Trinidad coal field lies in southeastern Colorado in the Raton Mesa coal region between the Great Plains on the east and the Sangre de Cristo Mountains on the west. The mesas are high tablelands eroded in coal-bearing Cretaceous and Tertiary rocks that are downfolded into the Raton basin.

The surface rocks of the area are relatively underformed and dip gently westward into the interior of the Raton basin. They represent an essentially continuous cycle of the Late Cretaceous and early Tertlary deposition. The plains to the east are marine shale and thin limestone comprising the Carlile, Niobrara, and Pierre formations. The resistant rocks of the coal field top the soft shale of the plains. In ascending order, these rocks consist of : the Trinidad sandstone, a near-shore marine deposit; the Vermejo formation, a coastal swamp deposit; the Raton formation, a flood-plain and swamp deposit; and the Poison Canyon formation, a conglomeratic deposit of terrestrial origin. Pennsylvanian, Permian, Jurassic, and older Cretaceous rocks crop out in the mountains to the west and probably underlie the mapped area. Eocene rocks that overlie the Poison Canyon in the interior of the basin have been removed from the area by erosion.
\end{abstract}

Folding, dike and sill injection, and uplift followed Flocene deposition, and the area was peneplaned by Miocene or Pliocene time. A broad uplift followed and the resulting erosion developed the present topography.

The area contains vast fuel resources of bituminous coking coal in the Vermejo and Raton formations. More than 80 million tons of coal has been produced from the area. Nearly 3 billion tons is estimated to remain in beds of mineable thickness. About one-tenth of the coal at the outcrop has been transformed into natural coke by igneous intrusives.

No oil or gas has been produced in the area and the surface rocks show no structures that might faror accumulation of oil and gas. However, stratigraphic traps may occur in an eastward-thinning wedge of Pennsylvanian rocks beneath the area.

\section{INTRODUCTION}

\section{LOCATION AND EXTENT OF THE ARTA}

The Trinidad-Aguilar part of the Trinidad coal field (fig. 17) includes about 320 square miles in southeastern Colorado bounded 


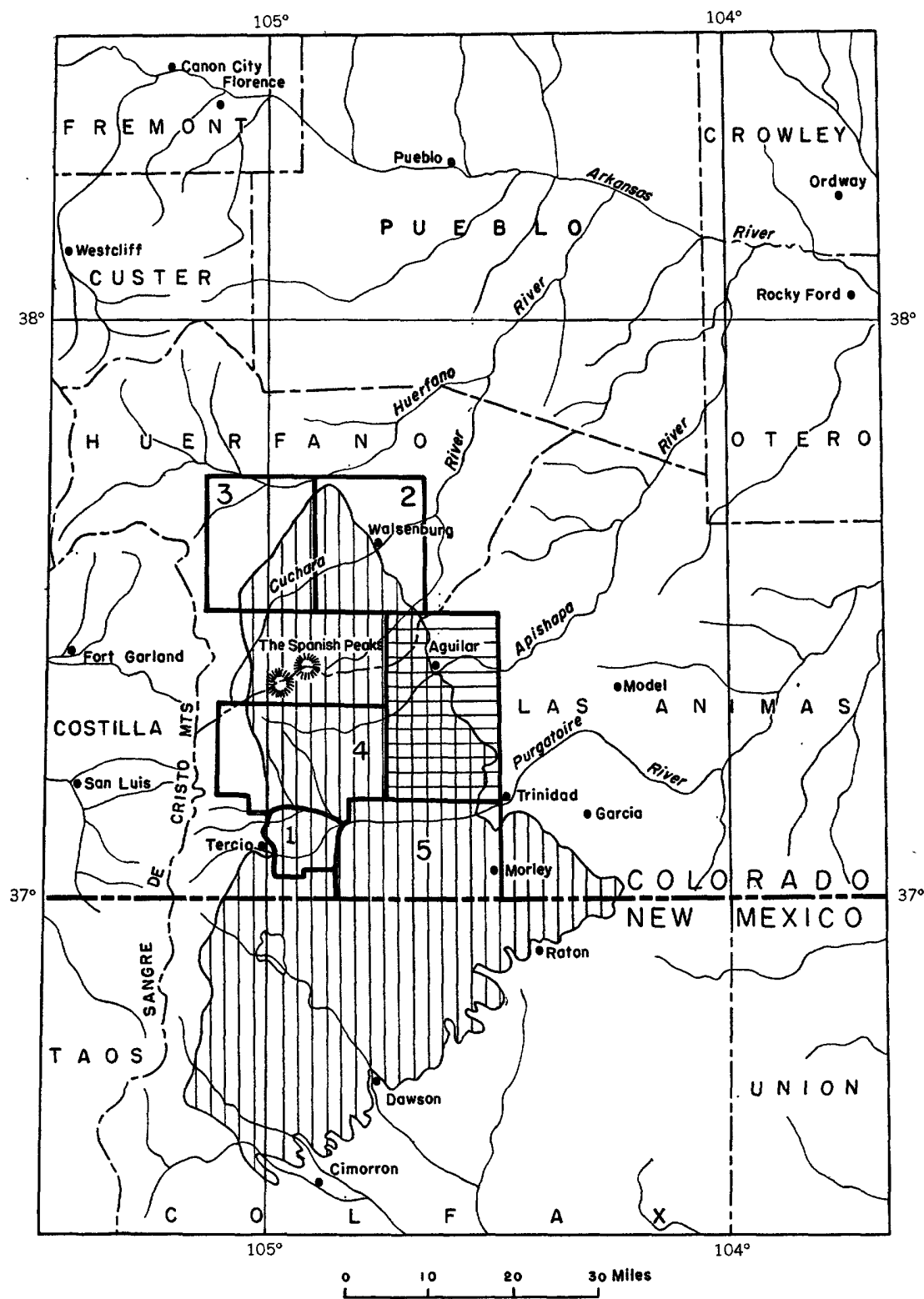

Figure 17.--Index map of Raton Mesa coal region (vertical shading) and the area of this report (horizontal shading). Other areas shown are: 1, The Stonewall-Terclo area (Wood, Johnson, and others, 1951) ; 2, the Walsenburg area (Johnson 1958); 3, the La Veta area (Johnson and Stephens, 1954a, 1954b) ; 4, the Gulnare area (Wood, Johnson and Dixon, 1956); and 5, the Starkvllle-Weston area (Wood, Johnson, and Dixon, 1957). 
by latitudes $37^{\circ} 10^{\prime}$ and $37^{\circ} 30^{\prime}$ and by longitudes $104^{\circ} 30^{\prime}$ and $104^{\circ} 45^{\prime}$. The rectangular area thus described, about 23 miles north and south, and 14 miles east and west, lies 12 miles north of the southern boundary of Colorado in Las Animas and Huerfano Counties. Trinidad, in the southeastern corner of the area, and Aguilar, in the northern part of the area, are the only incorporated settlements.

The area lies on the northeastern edge of the Raton basin, one of the larger structural depressions along the east front of the Rocky Mountains. Coal-bearing rocks of Cretaceous and Tertiary age have been downfolded into the depression and protected from erosion in an area measuring a maximum of 40 miles east and west and about 90 miles north and south.

In 1948 the Geological Survey began a program of detailed geologic mapping to evaluate the coal resources of the Raton basin. This bulletin is one of a series now in process of publication on the region. Other reports in the series are listed in the bibliography and located on the index map.

\section{PREVIOUS PUBLICATIONS}

Geologic observations in the Raton Mesa region began before the final acquisition of the region by the United States in 1845. The S. H. Long expedition to the Rocky Mountains traveled through the region and reported the occurrence of coal in the vicinity of Canon City to the north (James, 1821; Long, 1823). Military reconnaissance expeditions commanded by W. H. Emory (1848) and J. W. Abert (1848) discovered the coal of the Raton basin in 1846 and 1847. Owen and Cox (1865) also mentioned the occurrence of coal in the region.

After the Territory of Colorado was created in 1861, territorial surveyors visited this region and described the rocks (Hayden, 1867, 1868 a and b, 1873, 1874, 1876; St. John, 1876; Conkling, 1877; Endlich, 1877). The geologic features of the region were also described by J. L. Le Conte (1868) in a survey of a projected route of the Union Pacific Railway.

As the railroads were built westward, large-scale production of coal from the Trinidad (Colorado) and Raton (New Mexico) fields began. J. J. Stevenson $(1879,1881,1889)$ described the coal-bearing rocks of the fields. An excellent description of the general geology and the major rock units of the Trinidad-Aguilar area and the surrounding region appeared in three folios of the Geologic Atlas of the United States (R. C. Hills, 1899, 1900, 1901). The geology, coal resources, and age of the coal-bearing rocks of the Raton field were described and discussed by W. T. Lee $(1909,1911,1913,1916,1922$, 1924). G. B. Richardson (1910) measured and described the major coal beds of the Trinidad field at a time when the mines were approach- 
ing maximum production. Adolph Knopf (1936) outlined the igneous geology of the Spanish Peaks.

Descriptions of well-preserved plant remains and impressions collected from rocks of the coal field early stimulated speculation regarding the age of the coal beds. J. W. Bailey (1848), Le Conte (1868), Leo Lesquereux (1872, 1873, 1874, 1878, 1883), and J. S. Newberry (1874) described fossil plants collected from this region. F. H. Knowlton (Lee and Knowlton, 1917) and R. W. Brown (1943) published more recent studies of the flora and age relationships indicated by the collections.

Recent geologic reports in the region include the present series describing the geology and coal resources of the Raton basin. Other reports in the series which have been published include publications concerning the following areas: the Stonewall-Tercio area (Wood, Johnson, and others, 1951), the Walsenburg area (Johnson and Stephens, 1955; Johnson, 1958), the La Veta area (Johnson and Stephens, 1954a; 1954b), the Gulnare area (Wood, Johnson, and Dixon, 1956), and the Starkville-Weston area (Wood, Johnson, and Dixon, 1957). A preliminary geologic map of the Trinidad-Aguilar area has been published (Harbour and Dixon, 1956).

\section{FIELDWORK}

The fieldwork on which this report is based was done during the summers of 1951 and 1952. The geology was mapped on single-lens aerial photographs at scales of 1:20,000 and 1:24,000, which were furnished by the U.S. Soil Conservation Service and the Topographic Division of the Geological Survey. A radial base map was made from these photographs by means of metal templets, using triangulation stations of the Forest Service, the Geological Survey, and the Coast and Geodetic Survey for horizontal control. The drainage, geology, and culture were delineated on the photographs and transferred to the base map by the use of stereoscopic plotters. The position of the land lines was determined by field location on the photographs of the township corners. Section corner stones set by the original surveys before 1890 could not be found, but most of the township corners, which have been reset with iron pipes, were located. Vertical control for the structure contours was obtained from a line of bench marks established by the Coast and Geodetic Survey along the Colorado and Southern Railway and from preliminary topographic maps prepared by the Topographic Division of the Geological Survey for the southern quarter of the map area.

The geology was mapped by R. L. Harbour and G. H. Dixon. They were assisted in measuring the coal beds by R. L. Koogle and J. G. 
Stephens. The engineering firm of Douglas, Corey, and Fiske, Walsenburg, Colo., supplied information on many. of the coal mines. Nearly all of the land in the area is privately owned or leased for grazing, and all land holders and mine operators cooperated with the field party and permitted access upon request.

\section{GEOGRAPHY}

The Trinidad-Aguilar area lies partly in the Great Plains and partly in the high tablelands of the Trinidad coal field portion of the Raton Mesa region. To the east of the area lie the featureless plains; to the west the high tablelands are bordered by the rugged Sangre de Cristo Mountains. The most prominent geographic feature visible from the area is the Spanish Peaks which rise abruptly from the tableland 10,miles west of the area.

An almost continuous line of eastward-facing cliffs extends from Trinidad northwestward across the area and separates the tableland from the plains. The tablelands are intricately dissected and slope eastward from the high country surrounding the Spanish Peaks in a series of discontinuous steplike benches. The plains are broadly undulating and slope gently northeastward toward the Arkansas River. Low gravel-capped terraces and resistant dikes of igneous rock rise above the plains at places.

Total relief in the Trinidad-Aguilar area is about 2,000 feet. Altitudes within the coal field range from about 6,300 feet, where the canyons break out onto the plains, to abeut 8,000 feet on the divide between Santa Clara Creek and Apishapa River. The lowest elevation on the plains, 5,930 feet, is the point at which Apishapa River leaves the map area in sec. 30, T. 30 S., R. $63 \mathrm{~W}$. The highest point on the plains, 6,580 feet, is on Apishapa Crag, a dike ridge 8 miles east of Aguilar.

The drainage of the area is predominantly eastward, and alf the canyons drain into Arkansas River, 50 miles to the northeast. Canyons in the southern quarter of the area are drained southeastward into Purgatoire River, a major tributary of the Arkansas River that heads on the flanks. of the Sangre de Cristo Mountains to the west. Master streams, in addition to the Purgatoire, are Apishapa, River and Santa Clara Creek, which head on the slopes of the Spanish Peaks. The Purgateire and Apishapa Rivers flow northeastward directly into the Arkansas. The waters of Santa Clara Creek reach the Arkansas by way of Cucharas and Huerfano Rivers. Although the major canyons are drained eastward the bedrock dips gently westward, which indicates that the major stream pattern was established before the uplift of the region that started the latest erosional cyele. Stream $496794-59-2$ 
courses in the resistant rocks of the coal field are in steep-walled tortuous canyons of high gradient. The floors of the larger canyons are relatively wide; those of the tributaries are V-shaped in profile. In the soft shale of the plains, however, the water courses occupy flat valleys where braided channels and locally impounded drainages are common.

Purgatoire River, which flows through Trinidad, is the only perennial stream in the area, but many of the deeper canyons that dissect the coal field contain small ephemeral streams during rainy years. The gravel-filled bottoms of many of the canyons in the coal field are dependable sources of small flows of underground water. In the plains to the east, gravel is scarce and underground water is mostly obtained from wells that reach permeable layers in the Cretaceous bedrock. Bedrock in the coal field is usually saturated with water below the levels of adjacent canyons and many of the coal mines must be pumped. The Gem mine, at Aguilar, furnishes water for irrigation.

The climate of the region is semiarid and dry-farming is successful only at higher elevations. Most of the precipitation falls as summer thundershowers, although snow frequently covers the area in winter. The first heavy snowfalls usually occur early in November. July and August are the warmest months, December and January the coldest. Temperature and precipation records for Trinidad and nearby Walsenburg are given in the following table.

Climatic data from stations nearby

[Compiled from U.S. Weather Bureau statistics]

\begin{tabular}{|c|c|c|c|c|}
\hline & \multicolumn{2}{|c|}{ Trinidad } & \multicolumn{2}{|c|}{ Walsenburg } \\
\hline & $\begin{array}{c}\text { Precipitation } \\
\text { (inches) }\end{array}$ & $\underset{(\mathrm{F})}{\text { Temperature }}$ & $\begin{array}{c}\text { Precipitation } \\
\text { (inches) }\end{array}$ & $\underset{(\mathrm{F})}{\text { Temperature }}$ \\
\hline $\begin{array}{l}\text { January } \\
\text { February } \\
\text { March } \\
\text { April } \\
\text { May } \\
\text { June } \\
\text { July } \\
\text { August } \\
\text { September. } \\
\text { October } \\
\text { November } \\
\text { December }\end{array}$ & $\begin{array}{r}0.40 \\
.62 \\
.80 \\
1.79 \\
1.79 \\
1.37 \\
2.06 \\
1.83 \\
1.28 \\
.94 \\
.53 \\
.68\end{array}$ & $\begin{array}{l}30.9 \\
33.1 \\
39.9 \\
48.9 \\
57.5 \\
66.9 \\
71.6 \\
70.6 \\
63.5 \\
52.8 \\
41.5 \\
32.0\end{array}$ & $\begin{array}{r}0.65 \\
.69 \\
1.41 \\
2.22 \\
1.96 \\
1.09 \\
1.60 \\
1.43 \\
1.25 \\
.96 \\
.66 \\
.55\end{array}$ & $\begin{array}{l}32.8 \\
35.9 \\
41.1 \\
49.4 \\
57.7 \\
66.6 \\
71.2 \\
70.7 \\
63.2 \\
54.9 \\
42.4 \\
36.9\end{array}$ \\
\hline Annual average. & 14.08 & 50.8 & 14. 46 & 51.9 \\
\hline
\end{tabular}

Norr.-Length of record for the two stations is given below.

\begin{tabular}{|c|c|c|}
\hline & \multicolumn{2}{|c|}{ Length of record, in years } \\
\hline & $\begin{array}{c}\text { For } \\
\text { precipitation }\end{array}$ & $\begin{array}{l}\text { For } \\
\text { temperature }\end{array}$ \\
\hline $\begin{array}{l}\text { Trinidad. } \\
\text { Walsenburg.-........... }\end{array}$ & $\begin{array}{l}44 \\
18\end{array}$ & $\begin{array}{ll}42 \\
16\end{array}$ \\
\hline
\end{tabular}


Trees cover most of the coal field, but are scarce on the plains. The high parts of the coal field support stands of yellow pine that have been greatly thinned by cutting; the lower parts are covered by thickets of juniper, piñon, and scrub oak. On the low plains of the northeast, piñon and juniper grow only on outcrops of resistant rock in the Black Hills and in the valley of Salado Creek. Grass is abundant throughout the area, and several species of cactus thrive.

The natural transportation route through the area is on the plains, 1 to 2 miles east of the cliffs that form the boundary of the coal field. Along this route, U.S. Highway 85-87 and the Colorado and Southern Railway connect Trinidad and Aguilar with cities to the north. South of Trinidad, Highway 85-87 and a transcontinental route of the Atchison, Topeka, and Santa Fe Railway serve Trinidad and cities to the south and west by way of Raton Pass. Unpaved roads maintained by the State and county connect Trinidad and U.S. Highway 85-87 with the interior of the coal field. Roads in the coal field are mostly in the major canyons, and off-road automobile and jeep travel is greatly restricted by the topography and vegetation. Roads on the plains of the northeastern part are few, but jeep travel is restricted only by fences and deeply cut arroyos. Railroad spurs conect the Bear Canyon and Rapson mines in this area with the Colorado and Southern Railway. A new (1951) branch line south of the area connects Trinidad with the Allen mine in the upper valley of the Purgatoire River, 30 miles west.

With a decrease in coal production that has occurred progressively over the past few decades, the population of the area has declined. Ruins of once-prosperous mining towns attest this decline, and livestock-raising has replaced coal mining as the most important industry in the area. Trinidad, with 12,204 inhabitants in 1950, and Aguilar, with 1,038 , are the area's only incorporated towns. Small agricultural communities, each of less than ten families, remain in the old mining towns of Rouse, Delagua, Ludlow, Berwind, and Boncarbo. Valloroso, at the Bear Canyon No. 6 mine in Road Canyon, is the only remaining coal mining community. A few people reside at isolated ranchhouses.

\section{STRATIGRAPHY}

The sedimentary rocks exposed in the Trinidad-Aguilar area are predominantly clastic and range from Late Cretaceous to early Tertiary in age. The rocks in the exposed stratigraphic section, which is about 5,000 feet thick, are coarser toward the top, reflecting changes in sedimentation from off-shore marine shale to terrestrial conglomerate. The lower half of the stratigraphic section is exposed in the plains to the northeast. It consists of soft marine shale with lesser 
amounts of marine limestone. The upper half of the section crops out in the hills and mesas of the coal field. It consists of sandstone shale, conglomerate, and coal, and is mostly of nonmarine origin.

A thick section of sedimentary rocks that range in age from Pennsylvanian to Cretaceous probably underlies the Trinidad-Aguilar area. These older rocks are exposed in the Sangre de Cristo Mountains, 15 miles west of the area, and have been penetrated in wells drilled in the Great Plains to the east.

\section{BURIED ROCKS}

A wedge of Pennsylvanian and Permian rocks that thins eastward probably rests upon the Precambrian surface beneath this area. The oldest sedimentary rocks in the Sangre de Cristo Mountains to the west are marine limestone and clastic rocks of Pennsylvanian age. They grade upward into continental red beds of Pennsylvanian and Permian age. The marine rocks, environmental if not exact temporal equivalents of the Magdalena group of New Mexico, are at least 2,000 feet thick at the nearest exposures in the Sangre de Cristo Mountains. The continental red beds, which constitute the Sangre de Cristo formation, are about 10,000 feet thick at the nearest exposures. In contrast to the great thickness of these beds, a thin sequence of Permian rocks directly overlies the Precambrian in wells drilled east of this area in Colorado and New Mexico. Lateral variations in thickness of Pennsylvanian and Permian rocks are great and the sediments apparently were deposited in narrow troughs. Because of these variations, the thickness of strata of Pennsylvanian and Permian age beneath the mapped area is unknown.

Upper Jurassic formations, the Ocate and the Morrison, probably overlie the Permian. In the mountains to the west, the Ocate sandstone appears as a prominent white band between the deep red of the Sangre de Cristo formation and the overlying pastel red and green of the Morrison formation. The lower and upper boundaries of the Ocate sandstone parallel the bedding of the enclosing formations at single outcrops. Characteristically resistant and fine grained, the Ocate is about 50 feet thick. It was named by Bachman (1953) from exposures in the vicinity of Ocate, N. Mex., and appears to correlate with the Entrada sandstone of southwestern Colorado and the Exeter sandstone of northeastern New Mexico and the Panhandle of Oklahoma. The Morrison formation, about 250 feet thick in the mountains to the west, is composed of complexly interbedded mudstone, marl, limestone, and sandstone. In wells drilled east and northeast of Trinidad, equivalents of the Morrison and Ocate are separated from a thin Permian section by 150 feet of red shale and dolomito that may 
be of Permian and Triassic age (Bass, Straub, and Woodbury, 1947). These beds are lacking in the nearest mountain exposures, and may not extend into the area.

Rocks of Cretaceous age, gray and buff in contrast to the bright hues of the Morrison, are thought to overlie the Jurassic in the subsurface of the area. The Cretaceous rocks, exposed in the plains to the east and the mountains to the west, are relatively widespread and, compared with the older formations, are uniform in character and thickness over large regions. In ascending order, subsurface Cretaceous rocks and their probable thicknesses are: the Purgatoire formation, 100 feet, the Dakota sandstone, 50 to 200 feet, the Graneros shale, 200 feet, the Greenhorn limestone, 50 feet, and the Carlile shale, 200 feet. The Purgatoire and Dakota consist of buff and gray sandstone, conglomeratic at places and interbedded with carbonaceous shale. The Graneros and Carlile are composed of limey gray shale; the intervening Greenhorn limestone is characteristically light gray, fine grained, and thinly bedded. The base of the Cretaceous sequence is disconformable with, but generally parallel to, the underlying Morrison. Physical evidence of important stratigraphic breaks within the soquence is lacking, and recent stratigraphic work (Waagé, 1955, p. 42) suggests that the boundary between the Upper and Lower Cretaceous series may be within the Graneros shale in this area.

\section{EXPOSED ROCXS}

Rock formations exposed in the Trinidad-Aguilar area nized as early as 1901 by R. C. Hills, in his Spanish Peaks folio, and only minor revisions of his terminology are necessary :

\begin{tabular}{|c|c|}
\hline Spanish Peaks Follo 71 & This report \\
\hline Poison Canyon formation & Poison Canyon formation \\
\hline \multirow{2}{*}{ Laramie formation } & Raton formation \\
\hline & Vermejo formation \\
\hline Trinidad sandstone & Trinidad sandstone \\
\hline Pierre shale & \multirow{2}{*}{$\begin{array}{l}\text { Pierre shale and Niobrara formation } \\
\text { undivided }\end{array}$} \\
\hline Apishapa formation & \\
\hline Timpas formation & Fort Hays limestone \\
\hline Carlile shale & Carlile hale \\
\hline
\end{tabular}

The thickness and lithology of the units are shown on plate 11. 


\section{CRETACEOUS SYSTEM}

\section{CARLILE SHALE}

The upper part of the Carlile shale is exposed in a small area in the valley of Salado Creek in the northeast corner of the map area. It consists of soft dark-gray marine shale overlain by 4 feet of resistant purplish-gray sandy limestone that contains shell fragments and shark teeth.

The Carlile shale crops out in many of the Great Plains states and it was named by Gilbert (1896, p. 565-566) from exposures at Carlile station, 21 miles west of Pueblo, Colo. The sandy limestone bed at the top of the formation probably correlates with the Codell sandstone member described by Dane, Pierce, and Reeside (1937, p. 216220) north of the Arkansas River in eastern Colorado.

\section{FORT HAYS IIMESTONE MEMBER OF THE NIOBRARA FORMATION}

The Fort Hays limestone member of the Niobrara formation forms conspicuous cliffs along Salado Creek in the northeast corner of the map area. It is composed of resistant light-gray limestone in beds less than 2 feet thick that are separated by thinner beds of gray calcareous shale. The contact with the underlying Carlile is apparently conformable in this area.

Section of Fort Hays limestone member measured on south side of Salado Creek (SW $1 / 4$ sec. $26, T .29$ S., R. 64 W.)

Pierre shale, and Niobrara formation, undivided: Shale, light-gray, Feet

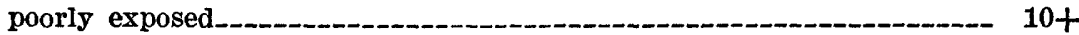

Fort Hays limestone member :

Limestone, thinly bedded, light-gray, hard, interbedded with gray calcareous shale. Limestone shale ratio, 4 to 1_-________-_-_ 32

Shale, gray, calcareous ; some gray limestone beds less than 6 in. thick_ 16 Carlile shale:

Limestone, purplish-gray, sandy, fossiliferous (Codell member) _-_-_ 4

Shale, gray, sandy. $10+$

The Fort Hays limestone member of this report is correlative with the Hays limestone as defined by Dane, Pierce, and Reeside (1937, p. 221-223). It corresponds to the lower part of the Timpas limestone described in this area by Hills $(1901$, p. 1).

\section{PIERRE SHALE AND NIOBRARA FORMATION, UNDIVIDED}

A thick sequence of marine shale, which consists of equivalents of the upper member of the Niobrara formation and the overlying Pierre shale, rests conformably upon the Fort Hays limestone in this area. The sequence crops out in the plains east of the coal field and is the surface rock of more than one-third of the map area. The lower part 
is poorly exposed in the valley of Salado Creek and appears to consist of light-gray chalky shale with a few thin limestone beds. Buff thinbedded sandstone, about 5 feet thick, crops out in the valley of Salado Creek in sec. 30, T. 29 S., R. 64 W. This sandstone, shown as line "A" on the map, is also expected in secs. 11 and 12, T. 30 S., R. 64 W., within the map area and, to the north and east of the map area, in sec. 14, T. 29 S., R. 65 W., and in sec. 17, T. 31.S., R. 63 W. The sandstone, about $\mathbf{4 0 0}$ feet above the Fort Hays, may correlate with the Apache sandstone of the Greenhorn Mountain area (Lavington, 1933, p. 399). The section above this sandstone is very poorly exposed to within 200 feet of the Trinidad sandstone, and appears to consist mostly of darkgray shale with rusty-weathering concretionary lenses of calcite and barite. The unit grades into and interfingers with the overlying Trinidad sandstone. The transition zone, which was mapped with the Pierre and Niobrara, consists of interbedded shale, siltstone, and sandstone. It is about 100 feet thick and becomes increasingly sandy toward the top. At places, the transition zone contains sandstone beds that are thick enough to map separately.

An unknown thickness of the lower part of the unit mapped as the Pierre shale and Niobrara formation may correlate with the Smoky Hill marl member of the Niobrara as defined by Dane, Pierce, and Reeside (1937, p. 223). Inasmuch as the Smoky Hill correlative in this area does not have the characteristic yellow color of that member, the Pierre and Niobrara formations can not be readily separated.

It is difficult to determine the thickness of the Pierre and Niobrara unit in this area. An estimate of 2,200 feet for the unit was obtained by planetable measurements from Salado Creek to sec. 4, T. 30 S., R. $65 \mathrm{~W}$. An estimate of 2,150 feet for the same interval was given by Hills (1901, p. 1) in the Spanish Peaks folio. These measurements are complicated by scarcity of exposures, and the thickness as shown by well logs at Morley dome, 6 miles southwest of Trinidad, is 2,640 feet.

\section{TRINIDAD SANDSTONE}

The Trinidad sandstone is the lowest and most prominent ledge exposed west of U.S. Highway 85-87 in the eastward-facing cliffs that separate the coal basin from the plains. It crops out as a single massive ledge above the softer beds of the transition zone in most exposures. Beds of massive sandstone occur in the transition zone below the main body of the Trinidad sandstone north of Aguilar in Ts. 29 and $30 \mathrm{~S}$., R. $65 \mathrm{~W}$., and east of Trinidad in T. 33 S., R. $64 \mathrm{~W}$. These beds merge southward with the Trinidad and wedge out northward in the transition zone. The interfingering relationship is shown on the map (pl. 10) and in the stratigraphic sections (pl.11). 
The Trinidad consists of buff and light-gray fine-grained sandstone in massive, tabular beds that are cross laminated in places. Thin lenses of gray sandy shale occur at a few localities. The sand grains, which are well sorted and subangular, consist of clear quartz with lesser amounts of weathered white feldspar and ferromagnesian minerals. Cement is calcite and clay. The buff varieties of sandstone are stained with limonite; the light-gray varieties contain carbonized plant fragments and resemble beds in the overlying Vermejo formation. Although generally porous at the outcrop, the sandstone beds locally contain thin, discontinuous layers of dark-brown sandstone extremely well cemented by calcite, concretionary in origin. Brown-weathering casts and molds of Halymenites sp., a marine fossil common in Cretaceous sandstone beds, are abundant in the Trinidad and do not occur in the overlying coal-bearing formations.

The Trinidad was named by Hills (1899) in the Elmoro folio. Hills included the basal transition zone with the massive sandstone above and designated the two units as the Trinidad formation. Lee (Lee and Knowlton, 1917, p. 48) designated the upper massive unit as the Trinidad sandstone and included the transition zone with the Pierre shale.

The Trinidad sandstone ranges in thickness from 70 to 150 feet in this area. It is about 300 feet thick to the north in the vicinity of La Veta, Colo. (Johnson and Stephens, 1954a), 45 to 150 feet thick southward toward the New Mexico State line (Wood, Johnson, and Dixon, 1957), and about 260 feet thick in wells drilled to the west near Stonewall, Colo.

\section{VERMEJO TORMATION}

The Vermejo formation is poorly exposed above the massive ledges of the Trinidad sandstone along the cliff that fronts the plains to the east. It is conformable with the Trinidad and crops out in steep talus-covered slopes capped by sandstone of the Raton formation.

The Vermejo formation consists of complexly interbedded gray to black shale, light-gray and buff sandstone, and coal. The shale, which constitutes about 60 percent of the formation, is mostly sandy and nonfissile. It contains ironstone concretions and abundant plant remains. The sandstone, which constitutes about 30 percent of the formation, is similar to the sandstone in the Trinidad. It occurs in lenticular beds that are as much as 40 feet thick. The beds are cross laminated at most places and are composed of fine to mediumsized grains of quartz, weathered white feldspar, and ferromagnesian minerals, cemented by calcite and clay. The sandstone is friable and contains carbonized plant fragments and mud pellets. The coal, which constitutes the remaining 10 percent of the formation, is of 
bituminous rank and has been extensively mined. The coal beds have a maximum thickness of 8 feet and occur throughout the formation.

The Vermejo formation averages about 150 feet in thickness in the southern part of the area and increases to about 270 feet at the northern boundary. It is 410 feet thick to the north in the vicinity of Walsenburg (Johnson, 1958), 80 to 140 feet thick southward toward the New Mexico State line (Wood, Johnson, and Dixon, 1957), and 220 to 380 feet thick to the west near Stonewall, Colo. (Wood, Johnson, and others, 1951).

In southern Colorado, the major variations in thickness of the Vermejo appear to be depositional features inasmuch as important stratigraphic breaks do not occur in the Trinidad-Vermejo-Raton sequence. The Vermejo grades into the underlying Trinidad in this area through a zone as much as 20 feet thick in which sandstone beds similar to the Trinidad alternate with carbonaceous shale beds. These sandstone beds do not contain Halymenites sp. and appear to have been reworked from the Trinidad. The two formations intertongue south of Dawson, N. Mex., according to Lee and Knowlton (1917, p. 4849 ). The contact of the Vermejo with the overlying basal conglomerate of the Raton formation appears to be locally disconformable in Road Canyon. At other places within the area, the contact is generally sharp, but conformable. Wood (Wood, Johnson, and Dixon, 1957, p. 23) indicates that the Vermejo and Raton interfinger in the valley of Purgatoire River, southwest of the Trinidad-Aguilar area. In the vicinity of Raton and Van Houten, N. Mex., the Vermejo formation is absent and the basal conglomeratic unit of the Raton formation rests unconformably upon the Trinidad sandstone (Lee and Knowlton, 1917, p. 94-97, 108-109).

The Vermejo formation was named by Lee (1913, p. 531) from exposures near Raton, N. Mex. The Vermejo is the lower part of the Laramie formation of the folios by Hills $(1899,1900,1901)$.

\section{TERTIARY SYSTEM}

\section{RATON FORMATION}

The Raton formation is the most extensively distributed rock unit in the Trinidad-Aguilar area and forms a series of benches and slopes above the Vermejo formation in the western part of the area. The outcrop band of the Raton trends northwestward and is 2 to 6 miles wide in the northern part of the area. In the southern part, the upper contact of the Raton swings westward and the formation crops out over a broad area because of entrenchment of the Purgatoire River and its tributaries. 
The Raton formation is separable into three general units in this area : a basal conglomerate, a middle coal-bearing unit, and an upper transition zone. These units were not mapped separately because of the thinness of the basal conglomerate, and the indefinite nature of the boundary between the middle and upper units.

The basal conglomerate of the Raton formation is generally parallel to the upper beds of the Vermejo formation and is the only reliable horizon marker above the Trinidad sandstone in this area. The unit consists of 2 to 75 feet of conglomeratic sandstone which, although extremely variable in lithology, occurs near the same stratigraphic position throughout the area. From Tingley Canyon (T. 32 S., R. 64 W.) northward it consists of light-gray crossbedded limonite-stained sandstone of coarse texture that contains chert pebbles as much as 1 inch in diameter. South of Tingley Canyon it generally consists of olive-green fine-grained sandstone that contains widely scattered quartz granules about one-eighth inch in diameter. The chert pebbles are gray to black and are well rounded, frosted, and weathered. The quartz granules consist of clear quartz and quartzite, well-rounded and frosted. At some localities, the conglomeratic sandstone occurs in two or three ledges separated by carbonaceous sandy shale. The basal conglomeratic unit is locally so well cemented by silica that its texture approaches that of quartzite. At other places it is extremely friable and crops out in pebble-strewn slopes.

A unit of coal-bearing rocks that comprises the major part of the Raton formation conformably overlies the basal conglomeratic sandstone. This unit, which averages about 1,000 feet in thickness, consists of gray to black shale, light-gray and buff sandstone, and coal. The lithology is similar to that of the Vermejo formation. The shale is mostly nonfissile and has a wide range of sand and carbonaceous content. The most common type of shale is gray, sandy, and slightly carbonaceous, but the types range from medium-gray shale composed of pure clay through sandy shale to shaly sandstone, and through carbonaceous shale to dirty coal. Irregular ironstone concretions occur in the shale. The sandstone beds have a maximum thickness of 40 feet and are more persistent than those in the underlying Vermejo. They are crossbedded and the grains range in size from fine to medium. The grains, well sorted to poorly sorted, consist of quartz, minor amounts of white feldspar and ferromagnesian minerals, and, at places, mica. Cement is calcite and clay ; irregular limonite staining is common. Many of the sandstone beds are dense and hard, others are friable. At a few localities, lenses of crossbedded sandstone as much as 100 feet thick fill channels in the underlying rocks. The 
coal is of bituminous rank and occurs in beds that have a maximum thickness of 6 feet. The coal beds have been extensively mined and are from 300 to 1,000 feet above the base of the Raton. There is some suggestion of rhythmic alternations in deposition of sand, clay, and vegetal material, in that order, within the Raton formation. Many of the coal beds are overlain directly by sandstone beds.

The top unit of the Raton formation in this area is a transition zone, 100 to 300 feet thick, that grades into the overlying Poison Canyon formation. This zone is composed of yellow and gray shale, buff and light-gray sandstone, and thin beds of coal. The yellow shale is sandy and not very fissile. It is barren of plant fossils and resembles the shale in the overlying Poison Canyon formation. The gray shale is carbonaceous and similar to the shale in the underlying part of the Raton formation. The sandstone is crossbedded, and occurs in beds as much as 40 feet thick. It is fine to coarse grained, and locally conglomeratic. Quartz is the predominant mineral constituent of the sandstone. The fine-grained varieties of sandstone contain traces of white feldspar and ferromagnesian minerals. The coarser grained varieties contain abundant white feldspar and flakes of muscovite. The granules and pebbles in the conglomeratic sandstone beds are angular fragments of white feldspar. The sandstone beds are poorly cemented to well cemented by clay and calcite. The coal of the transition zone is in beds that are of short horizontal extent and all are less than 14 inches thick.

The Raton formation ranges in thickness from about 1,000 feet at the northern boundary of the area to more than 1,300 feet in the southern part of the area. Although the layers within the formation are broadly parallel and regionally conformable, irregular undulations of the beds occur locally. The undulations are the result of differential compaction of the heterogeneous beds of the formations and intraformational unconformities of short horizontal extent. Sharp rolls in the mines and at the outcrops of the Raton coal beds are characteristic. Local angular unconformities occur in the lower part of the formation at places where flat-lying rocks overlie near-vertical strata for distances as much as 100 feet along the outcrop. The undulations and angularities within the formation are best exposed in the relatively flat areas of low regional dip in the southern part of the area, especially in T. 33 S., R. 65 W.

Strata assigned to the Raton formation occur throughout most of the Raton basin and the base is conglomeratic at most localities. South of this area, the Raton formation ranges in thickness from 1,200 to 2,000 feet (Lee and Knowlton, 1917, p. 57-58). A short distance to the north, however, the Raton is beveled by erosion and there is an 
unconformity at the base of the Poison Canyon formation (Johnson, 1958, p. 564).

The Raton formation was named by Lee (1913, p. 531) from exposures in the high mesa region between Trinidad, Colo., and Raton, N. Mex.. Lee (Lee and Knowlton, 1917, p. 56) concluded that the boundary between the Cretaceous and Tertiary systems was at the base of the Raton formation. A review of the paleontologic evidence by Brown (1943, p. 82-83) indicated that the systemic boundary is above the basal conglomeratic sandstone and below the major coal beds of the formation.

\section{POISON CANYON FORMATION}

The lower beds of the Poison Canyon formation are at the surface in the high country of the western part of the Trinidad-Aguilar area. These beds dip gently westward and are the remnants of a thick sequence of Tertiary rocks exposed in the deeper parts of the Raton basin to the west. The Poison Canyon formation crops out at altitudes higher than 6,700 feet, and good exposures are limited to steep-walled canyons and mesas because of heavy soil and vegetation cover.

The Poison Canyon formation in this area consists of massive buff to yellow conglomeratic sandstone interbedded with yellow sandy shale. The sandstone is commonly in obscurely laminated beds, from 10 to 50 feet thick, which have cavernous weathered surfaces irregularly stained red. Medium- to coarse-grained quartz predominates in the sandstone. Clasts of the conglomerate, which have a maximum diameter of 2 inches, are fairly well rounded and concentrated in scattered lenses within the sandstone beds. Angular pink and white feldspar granules and pebbles are common, and granules and pebbles of quartz, quartzite, gneiss, and chert occur at places. The yellow sandy shale of the Poison Canyon formation is obscurely bedded and not very fissile. The shale is rarely exposed, and weathers to a soft puffy texture. The basal beds of shale contain traces of badly crushed plant fragments.

The lower beds of the Poison Canyon formation that are preserved in this area constitute more than half of the normal thickness of the formation. The maximum thickness remaining in this area, about 1,300 feet, occurs along the boundary between Las Animas and Huerfano Counties in T. 30 S., Rs. 65 and $66 \mathrm{~W}$. The beds in this section become coarse upward; the lower part is composed of approximately equal amounts of sandstone and shale, whereas the upper part, which is exposed in high mesas along the county line, is predominantly sandstone. The contact between the Poison Canyon and Raton formations in this area is gradational, and is chosen arbitrarily. The con- 
tact shown on the map and stratigraphic sections was generally placed at the base of the first conglomeratic sandstone bed above the highest carbonaceous shale or coal bed.

The full thickness of the Poison Canyon formation is limited by erosion to the deeper parts of the Raton basin, west and northwest of the Trinidad-Aguilar area, where the Poison Canyon is overlain by a thick sequence of continental beds of Eocene age. From 2,100 to 2,500 feet of strata assigned to the Poison Canyon occur in the vicinity of the Spanish Peaks, 10 miles west of the Trinidad-Aguilar area. The lower few hundred feet of the formation crops out south of the Trinidad-Aguilar area in the high mesas between Trinidad and Raton, N. Mex. (Wood, Northrop, Griggs, 1953).

The age of the Poison Canyon formation has not been precisely determined because it has not yielded identifiable fossils. The formation is assigned to the Paleocene because of its stratigraphic position. It occurs above a Paleocene flora in the Raton formation, and below an Eocene vertebrate fauna in the Huerfano formation at Huerfano Park, Colo.

\section{QUATERNARY SYSTEM-GRAVEL}

The isolated patches of flat-lying Quaternary gravel shown on the map cap low buttes that rise above the plains. These gravel deposits are less than 20 feet thick and are composed of poorly sorted debris derived from the sedimentary and igneous rocks of the coal field. The larger fragments of the gravel are boulder size and include angular pieces of sandstone, intrusive igneous rock, shale, and coal that have undergone little abrasion. At most places, the gravel is poorly exposed and the contact with the underlying shale of the Pierre and Niobrara formations is covered. Where exposed, the basal beds of gravel are well cemented by lime.

These remnants of gravel deposits may mark the position of ancient stream valleys. They are not remnants of a single extensive deposit because many of the outcrops are separated by higher ridges carved on older rocks. The gravel was evidently transported through the present gaps in the western edge of the coal field because the projected bases of the gravel are below the cliffs at the sides of the gaps. Linear gravel outcrops in Ts. 29 and 30 S., R. 65 W., are alined with the gap in the coal field occupied by Apishapa River at Aguilar and may mark an ancient stream course on a higher level of that river, which has since been modified by stream capture.

The physical relationship of these gravel deposits to each other and their similarity to recent valley fill indicate that they are relatively recent in age. They are provisionally assigned to the Pleistocene, although they probably vary slightly in age. 
Recent valley fill, not shown on the map, occurs in the bottoms of most of the major canyons and valleys in the area. The outcrops are narrow and discontinuous in the coal field, and are obscured by residual mantle on the plains.

\section{IGNEOUS ROCKS}

Narrow dikes and thin sills of tough, fine-grained, gray to darkgreen igneous rock are abundant in the Cretaceous and Tertiary sedimentary rocks in the Trinidad-Aguilar area. The igneous rocks range from intermediate to mafic in composition and are porphyritic in texture. The ground mass is fine grained, and the phenocrysts of hornblende, augite, feldspar, olivine, and biotite rarely exceed 2 millimeters in diameter. The host rocks of the dikes and sills have been baked and hardened for short distances and coal adjacent to the intrusive rocks has been transformed into natural coke of dull luster and columnar jointing. The contacts of the igneous rocks with the host rocks are sharp, and there is no evidence of chemical assimilation.

The dikes of the Raton basin belong to two systems. One system radiates from the vicinity of the Spanish Peaks west of this area; the other system is a parallel set of eastward-trending dikes that occur throughout the Raton basin. The dikes are as much as 50 feet thick, 15 miles long, and 5,000 feet in vertical relief. They are all nearly vertical and probably were emplaced after the downwarping of the Raton basin. Dikes are more numerous in the comparatively brittle rocks of the coal field than in the pliant shale of the plains.

The sills, sheets of igneous rock intruded along bedding planes of the sedimentary formations, are less conspicuous than the vertically emplaced dikes. Some of the nonporphyritic varieties of sill rock resemble siltstone, but their intrusive origin is indicated by baking of the enclosing rocks, and by interwoven contacts. Vertical jointing is conspicuous in the sills. Interlacing of the sheets and the enclosing rocks is common, and many sills contain randomly oriented blocks of coal and shale which have been stoped and transported. The sills were emplaced mechanically; no evidence of chemical dissolving of the host rock was found. The sheets range from a few inches to 50 feet in thickness, and none can be traced laterally more than 5 miles. The relatively short horizontal extent indicates that the sills were fed by nearby dikes, the only adjacent igneous bodies that cut across bedding planes. Many sills terminate in dikes of similar composition, but such intersections are commonly obscured by soil and talus. Unlike the dikes, the sills did not intrude the Poison Canyon or younger formations in the Raton basin. Coal-bearing strata within the Vermejo and Raton formations provided favorable horizons for sill injection, and the heat of these intrusions made large quantities of coal 
worthless. Sills are more numerous than dikes in the shale of the Pierre and Niobrara formations and in the Black Hills, T. 31 S., R. 64 W., where there are at least four closely spaced levels of sill injection.

It is difficult to determine the age of the igneous rocks. In his classic description of the igneous rocks of the Spanish Peaks quadrangle, Hills (1901, p. 4) provisionally assigned the oldest to the Eocene, and determined from dike intersections that as many as 15 distinct dike eruptions of 8 igneous rock types occurred in this part of the Raton basin. The Huerfano formation, youngest of the rocks downfolded into the basin, is cut by the dikes. Sedimentary rocks younger than the Huerfano (Eocene), lie on the older sedimentary rocks and the dikes, but the age of these younger rocks is unknown. The large number of petrographically distinct dike eruptions in the region suggests that igneous activity may have continued for a considerable period of time. The most recent intrusive magma in this area may have been associated with post-Pliocene basalt flows in the high mesas between Trinidad, Colo., and Raton, N. Mex. (Wood, Northrop, and Griggs, 1953). At least 7,000 feet of sedimentary rocks have been removed by erosion since the emplacement of the oldest dikes.

\section{GEOLOGIC STRUCTURE}

The Trinidad-Aguilar area lies in the northeastern part of the Raton basin and the basinal structure is modified or obscured by monoclinal folding, jointing, intraformational warping, and recent weathering. Of these minor features, only monoclinal folding and jointing extend into the underlying rocks, and the configuration of the structure contours on the geologic map ( $\mathrm{pl} .10$ ) is the result of downwarping of the basin and monoclinal folding.

The Raton basin is a broad asymmetrical syncline that trends northward and is characterized by a steep western limb, a gently sloping eastern limb, and a broad central portion in which the beds are essentially horizontal. The steep western limb is bordered by rocks thrust eastward from the Sangre de Cristo Mountains and the eastern limb, upon which the Trinidad-Aguilar area is located, culminates in the Las Animas arch, a structural swell in the Great Plains to the east. The cliffs on the eastern border of the coal field closely parallel the strike of the basinal structure, and the rocks of the cliffs dip westward and southwestward from a maximum angle of $10^{\circ}$ in the northern part of the mapped area to about $1^{\circ}$ on the southern boundary. The dip flattens westward toward the central part of the basin and the beds are essentially horizontal in the southwestern part of the mapped area. Structure contours are not shown on the geologic map in the plains east of the coal field because of a scarcity of datum planes, but 
in the northeastern corner of the mapped area, the Fort Hays limestone dips southward at an angle of $1^{\circ}$.

A narrow, slightly sinuous monoclinal flexure passes through the abandoned workings of the Brodhead mine and old Green Canyon mine, 3 miles northwest of Aguilar. The monocline trends northeastward and the rocks on the northwest side are downfolded through a zone less than a quarter of a mile wide. Dips in the zone of flexure approach $50^{\circ}$ at places, and the vertical displacement increases southwestward from about 50 feet at the eastern edge of the coal field to a maximum of nearly 200 feet near the western border of the area. The flexure is sharp; at places the rocks change in dip from less than $2^{\circ}$ to more than $40^{\circ}$ in horizontal distances of less than 400 feet. Individual bedding planes can be traced unbroken across the zone of flexure a short distance northeast of Mauricio Canyon. The southwestward extension of the monocline from Mauricio Canyon is covered by soil and vegetation, and the flexure may terminate in the vicinity of the western border of the area. The monocline can be traced through beds of the Trinidad, Vermejo, Raton, and Poison Canyon formations. Dikes that pass through the zone of flexure remain vertical, and the flexure is thus older than the dikes. The sharpness of the folding suggests that the rocks may have been poorly consolidated, and the monocline folding may be older than the downwarping of the Raton basin.

Vertical joints intruded by dikes of igneous rock are abundant in the coal field (p. 462). The joints belong to two systems and are probably tension fractures that formed parallel to compressive forces. The radial system probably resulted from outward pressure exerted by the emplacement of the stocks of the Spanish Peaks. The joints of the east-west system are perpendicular to the front of the Sangre de Cristo Mountains and may have resulted from compression caused by the eastward thrusting of the mountains.

Undulations of bedding planes caused by differential compaction and intraformational unconformity locally obscure the broad structural features of the coal field. In the rocks of the Raton formation the undulations are conspicuous (p. 459) and are difficult to distinguish from folding that extends into the underlying rocks. Structure contours are not shown in the southwestern part of the geologic map (pl. 10) because these intraformational undulations within the Raton formation prevent accurate estimation of the depth to the Trinidad sandstone.

Expansion of clay-bearing rocks on weathering has apparently produced false attitudes in the bedrock in the Trinidad-Aguilar area. In most hillside mine tunnels, the coal beds dip steeply into the hill 
before resuming flatter attitudes in the unweathered portions of the mines. The same phenomenon is exposed by railway and road cuts in the plains to the east where bedrock in most hills is synclinal in crass section. Structure contour maps based on strikes and dips are likely to show false anticlines occupying all stream courses in the area.

\section{GEOLOGIC HISTORY}

The geologic events of the Proterozoic era are imperfectly known from exposures of rocks of that age in the Sangre de Cristo Mountains. As in many regions these rocks are exceedingly complex in structure, and determination of a detailed chronology of Precambrian geologic history awaits further study in this region.

A great thickness of sediments was deposited in this region at some time during the Proterozoic era. The sediments were metamorphosed by intense folding and faulting, and by the intrusion of large bodies of granitic rocks later in Precambrian time. The metamorphism of the sediments was generally intense, but locally it was only moderate and did not obscure the bedding structures. At the close of Precambrian time, the rocks were probably subjected to widespread erosion, which reduced the land surface to a relatively flat, featureless plain.

Geologic events of the early part of the Paleozoic era are not recorded in the sedimentary rocks of this region, as rocks of Pennsylvanian age rest directly upon the Precambrian basement rocks. Parts of Colorado and New Mexico, however, were invaded by early Paleozoic seas, and carbonate and fine clastic sediments were deposited on the smooth Precambrian floor. The absence of angular unconformities and the fineness of these sediments suggest that this region was relatively stable and low-lying throughout the early part of the Paleozoic era. The region may have remained slightly above sea level and neither furnished nor received sediments during Cambrian through Mississippian times, but it seems more likely that early Paleozoic seas invaded the region and that any sediments that accumulated were removed by pre-Pennsylvanian erosion.

The events of the late Paleozoic era in southern Colorado are not well known. Read and Wood (1947) reviewed the distribution of Pennsylvanian rocks in northern New Mexico, however, and concluded that Pennsylvanian and Permian rocks there represent a single major sedimentary cycle in northward-trending basins. These conclusions are probably applicable to the late Paleozoic rocks of southern Colorado.

During the Pennsylvanian and Permian periods a great thickness of sediments was deposited in the Rowe-Mora basin, a Pennsylvanian 
and Permian geosylcline, that trended northward and lay between the highlands of the Sierra Grande geanticline to the east of this area, and the Uncompahgre geanticline to the west. In early Pennsylvanian time a sea transgressed the region and sediments began to accumulate in the basin. These sediments consisted of carbonates, which were precipitated from the sea, and clastic deposits, some very coarse, derived from the bordering highlands. The highlands were uplifted and the intervening basin depressed intermittently during the Pennsylvanian and Permian periods. Toward the end of Pennsylvanian time, the rate of supply of sediments gradually exceeded the rate of subsidence in the basin, and the sea retreated. Fluctuations of the strand line as the sea withdrew southward left a zone of intermixed marine and nonmarine sediments. Subsidence of the basin and uplift of the highlands continued after the sea finally withdrew, and probably reached a climax in the early part of the Permian period, during which a great thickness of clastic sediments accumulated on the basin floor. Toward middle Permian time uplift in the highlands ceased. The highlands were reduced by erosion toward base level, and sedimentation in the basin diminished and eventually ceased. The rocks of the basal marine phase of the Pennsylvanian and Permian depositional cycle are commonly referred to the Magdalena group, and rocks of the nonmarine phase constitute the Sangre de Cristo formation.

Events of the latest part of the Paleozoic and the early part of the Mesozoic eras are not recorded in the sedimentary rocks of the nearby Sangre de Cristo Mountains, where the Ocate sandstone of Late Jurassic age rests with apparent conformity upon the Sangre de Cristo formation of Pennsylvanian and Permian(?) age. The apparent conformity is misleading and represents a long interval of time (middle Permian to Late Jurassic) during which sedimentation continued intermittently in nearby regions. During this interval of time, the Lykins formation of Permian(?) and Triassic(?) age was deposited to the north, and the Dockum group of Late Triassic age was deposited to the east and south. Any deposits that may have accumulated here during this time were removed by erosion prior to the deposition of the Ocate.

During the Late Jurassic epoch, the remarkably widespread and uniformly fine-grained sand of the Ocate formation was deposited in this region, possibly at the front of a shallow sea that quickly retreated. The land lay slightly below base level after the deposition of the Ocate, and mud, sand, and lime accumulated in lakes to form the lower part of the Morrison formation. Deposition continued slowly and intermittently under subaerial conditions as the variegated, 
fine-grained sediments of the upper part of the Morrison were deposited.

During most of the Early Cretaceous epoch, southeastern Colorado lay near base level and erosion of the Morrison formation was slight. Eastward in Texas and Oklahoma thick deposits were accumulating in a sea that transgressed slowly northward. The sea reached this part of Colorado in the latter part of Early Cretaceous (Washita) time, and the sand and mud of the Purgatoire formation accumulated along the advancing strand line. The sea then withdrew, and carbonaceous mud of the upper part of the Purgatoire formation accumulated in swamps near shore.

Later in Early Cretaceous time, the sea reflooded the region from the southeast, and along the strand line, the sand, mud, and carbonaceous material of the Dakota sandstone were deposited. The Dakota was a basal sandy phase of a marine cycle of deposition that continued through late Early Cretaceous and most of Late Cretaceous time. The sandy phase (Dakota) was succeeded by the deposition of the clay and lime of the Graneros, Greenhorn, Carlile, Niobrara, and Pierre formations, which were deposited in the sea relatively far from shore and below disturbance by wave action. During this marine cycle deposition seems to have been essentially continuous.

The sea retreated slowly eastward across this region late in the Cretaceous period, either as a result of gentle uplift or of oversupply of sediments. The Trinidad sandstone accumulated in the retreating sea near the strand line, and the mud, sand, and carbonaceous material of the overlying Vermejo formation were deposited in flood plains, swamps, and deltas on the landward side of the strand line.

Toward the close of the Cretaceous period, orogenic disturbances west of this region initiated the Laramide revolution and resulted in the deposition in this area of the widespread unit of conglomeratic sand that forms the base of the Raton formation. Environmental conditions apparently remained unchanged, however, and the mud, sand, and carbonaceous material of the main part of the Raton formation were deposited in an environment similar to that of the Vermejo. Deposition of the coal-bearing formations (Vermejo and Raton) appears to have been essentially continuous from Late Cretaceous into Paleocene time, and the occurrence of a zone barren of coal beds of commercial thickness above the basal conglomeratic unit of the Raton formation may mark a period of rapid sedimentation resulting from the initial Laramide orogeny.

Deposition of the fine-grained sediments of the Vermejo and Raton formations in this region was succeeded by deposition of the coarse clastic debris of the Poison Canyon formation during the Paleocene 
epoch. The transition from fine-grained carbonaceous sediments to coarse clastic sediments was gradual in this area and to the south. To the north in the vicinity of Walsenburg, however, the Poison Canyon was deposited after the older rocks had been tilted to the southeast and truncated by erosion. The sediments of the Poison Canyon formation were apparently derived from areas uplifted by Laramide mountain building to the northwest.

Orogenic disturbances to the west continued into the Eocene epoch, and a thick sequence of continental sediments accumulated to form the Cuchara and Huerfano formations, which are preserved in the vicinity of the Spanish Peaks. These formations apparently mark the end of subsidence and deposition in this area.

After the Huerfano formations of Eocene age was deposited, the region was raised above base level by the orogenic uplifts that had originated to the west. These orogenic forces produced the major structural features of the Sangre de Cristo Mountains and the Raton basin. The monoclinal fold was formed, the western limb of the basin was upturned, stocks and dikes of the Spanish Peaks were emplaced, and tension fractures formed across the basin and were invaded by igneous material.

Two major Tertiary and Quaternary erosional cycles have removed at least 7,000 feet of rocks from this area since the deposition of the Huerfano formation of Eocene age. The first cycle resulted from orogenic uplift in the latter phases of the Laramide revolution. The second cycle resulted from epeirogenic uplift after Miocene and Pliocene peneplenation of the region and the deposition of the Ogalalla formation east of this area. The second cycle of erosion is apparently still in progress. The thin linear sheets of gravel on the plains were deposited during the downcutting of the area and owe their preservation to cementation during interruptions in their transportation along stream bottoms (p. 461).

\section{OIL AND GAS POSSIBILITIES}

There has been some exploration for oil and gas in the Raton Mesa region because the thick stratigraphic section contains promising source and reservoir rocks. Thick sequences of marine shale in the Pennsylvanian and Cretaceous systems are commonly petroliferous at the otucrop. Permeable beds that could serve as effective reservoirs are interbedded with the marine shale of the two systems. Oil and gas exploration in this region, however, has been limited almost entirely to Cretaceous formations.

The most promising potential reservoir rocks in the Cretaceous are, in descending order, the Trinidad sandstone, the Dakota sandstone, 
and the Purgatoire formation. The Dakota and Purgatoire have been tested, with discouraging results, at domes near Morley and Tercio in the Colorado part of the Raton basin. The Trinidad, breached by erosion at these domes, has not been adequately tested.

The Pennsylvanian system in the Sangre de Cristo Mountains contains petroliferous beds of sandstone and conglomerate. However, the Pennsylvanian rocks have not been adequately tested in this region because they are separated from the Cretaceous by as much as 10,000 feet of red beds belonging to the Sangre de Cristo formation. Pennsylvanian rocks are absent in wells drilled east of the TrinidadAguilar area and probably form an eastward-thinning wedge beneath the area.

No domes or anticlines were found in the Trinidad-Aguilar area, and any accumulations of oil and gas are thus probably confined by stratigraphic traps. Because of the westward regional dip of the rocks in the area, the most favorable traps would be formed by eastwardlensing permeable strata. The eastward-thinning of the Pennsylvanian strata in the region suggests that individual permeable layers may pinch out eastward and form favorable stratigraphic traps.

The nearest oil fields are at Canon City and Florence, 80 miles northwest of Trinidad. Some gas has been produced from fields at Garcia, 10 miles southeast of Trinidad, and at Model, 30 miles to the northeast. The producing horizons at Canon City, Florence, and Garcia are in the Cretaceous marine shale sequence. The producing horizon at Model is in the Lyons sandstone in the upper part of the Permian. The Lyons is probably not present as far south as the Trinidad-Aguilar area.

Three wells drilled for oil and gas in the Trinidad-Aguilar area were abandoned as dry holes (see following table). These wells, which were not on structural "highs," were shallow and did not test the Pennsylvanian.

Wells drilled for oil and gas in the Trinidad-Aguilar area

\begin{tabular}{|c|c|c|c|c|c|c|}
\hline \multicolumn{3}{|c|}{ Location } & \multirow{2}{*}{ Company and well } & \multirow{2}{*}{$\begin{array}{l}\text { Year } \\
\text { com- } \\
\text { pleted }\end{array}$} & \multirow{2}{*}{$\begin{array}{l}\text { Total } \\
\text { depth } \\
\text { (ft) }\end{array}$} & \multirow{2}{*}{$\begin{array}{l}\text { Surface } \\
\text { formation }\end{array}$} \\
\hline $\begin{array}{l}\text { Town. } \\
\text { ship (S) }\end{array}$ & $\underset{(W)}{\text { Range }}$ & Section & & & & \\
\hline 29 & 65 & SW1/4 SE1/4 sec. 26 & \multirow{3}{*}{$\begin{array}{l}\text { Huerfano Oil \& Gas Co., A. T. } \\
\text { Stewart No. 1. } \\
\text { Pacific Coast Gasoline Co., } \\
\text { Cortese No. 2. } \\
\text { Atchison, Topeka \& Santa Fe } \\
\text { Railway Co. }\end{array}$} & 1933 & 2,103 & Pierre sh. \\
\hline 32 & 65 & NE1/4 sec. 34..... & & 1927 & 1,600 & Raton $\mathrm{fm}$. \\
\hline 33 & 64 & NE $1 / 4$ sW1/4 sec. 12 & & $?$ & 2,713 & Pierre sh. \\
\hline
\end{tabular}


COAL

\section{OCCURRENCE AND DISTRIBUTION}

The coal beds of the Trinidad-Aguilar area occur in the Vermejo and Raton formations above the Trinidad sandstone, which forms the prominent eastward-facing scarp west of U.S. Highway 85-87. The coal beds of workable thickness occur in two zones separated by a relatively barren interval at the base of the Raton formation. The individual beds of these zones are characterized by lack of continuity. Shale partings are common, and some of the coal beds split laterally into two or more beds separated by several feet of shale or sandstone. Carbonaceous shale is the most common floor and roof material of the coal beds. Coking of the coal by sills is common, especially in the Vermejo formation.

Sections of the coal beds that are more than 14 inches thick are shown graphically on plates 12,13 , and 14 . Most of the beds thicker than 28 inches have been mined and are given informal names in the graphic sections. The outcrop position of the coal beds are shown on the geologic map (pl. 10).

The lower coal zone consists of the coal beds of the Vermejo formation. The coal zone is from 110 to 270 feet thick and lies immediately above the Trinidad sandstone. The top of the zone is marked by the basal conglomeratic sandstone of the Raton formation. This basal conglomerate appears to be regionally conformable with the Vermejo, but rests on an erosion surface between Apishapa River and Chicosa Canyon, localities 18-34.

Coal beds of the Vermejo are randomly distributed throughout the formation. They are as much as $\mathbf{8}$ feet thick and are of short lateral extent. Of 15 coal beds in the Vermejo given informal names in this report, none extends throughout the area. However, at least one of these beds is present at every locality visited. As many as 4 coal beds thicker than 28 inches occur in the Vermejo near the northern border of the area where the formation is thickest. Coal beds near the base of the formation appear to be more persistent than those in the upper part, and mineable beds occur within a few feet of the top of the Trinidad sandstone at most localities. A few of the coal beds are directly overlain at places by the basal conglomeratic sandstone of the Raton formation.

The upper coal zone consists of the coal beds of the Raton formation (pl. 13 and 14). Coal beds thicker than 28 inches are limited to a zone about 500 feet thick in the middle of the formation. Individual coal beds are lenticular and the zonal boundaries are indefinite. 
The coal beds in the Raton are, on the average, thinner, less persistent, and more impure than those in the Vermejo formation. In the Raton formation thick barren intervals separate the coal beds and they are difficult to trace because of the lack of reliable datum planes upon which stratigraphic measurements can be based. Of 9 coal beds in the Raton given individual names in this report, no more than three occur at any single locality and no coal beds of workable thickness were found in parts of T. 33 S., Rs. 64 and 65 W., although exposures are somewhat scarce. Despite a general lenticularity in the upper coal zone, the Delagua No. 1 coal bed appears to bo the most persistent in the area, and has been correlated for a horizontal distance of about 15 miles. This bed lies about 700 feet above the base of the Raton and apparently splits into two beds at its northern and southern extremities.

\section{PHYSICAL AND CHEMICAI PROPERTIES}

The coals of the Vermejo and Raton formations are similar in appearance. The luster of the fresh coal, free of impurities, is invariably bright. Most of the coal is fractured, either cubically or prismatically, and, in some of the mines, this cleating is so marked that coal can be readily removed from the faces by pick. Some of the coal beds yield spherical bodies of coal as much as 2 feet in diameter which are evidently caused by squeezing within the beds. These bodies are highly prized as domestic fuel. Some of the more impure coals have platy cleavage. Nearly all of the coal beds contain impurities, and faces of coal without dirty streaks are found in only a few mines. The impurities that add significantly to mining costs are layers of bony and dirty coal, and partings of shale and sandstone. Limonite, sulfur, pyrite, and rosin are conspicuous, although present in only minor amounts. These minor impurities are more often found on the cleat faces than on the bedding planes of the coal.

The coal deteriorates, both physically and chemically, on weathering. The weathered coal is characteristically soft and stained with limonite. It is intricately fractured and, at a few localities, is reduced to powder that can be scooped out by hand. The deterioration apparently results from oxidation by alternate wetting and drying near the surface: water saturated coal beds that crop out in canyon bottoms are invariably tough and hard, but coal outcrops in hillsides are badly weathered. Coal that lies above nearby canyon bottoms where overburden is not thick is likely to be useless commercially because of weathering. 
Much of the coal adjacent to igneous rocks has been converted into natural coke by a process of devolatilization resulting from heat. This natural coke is characteristically dull, tough, and columnarly jointed. The jointing is polygonal, and is developed at right angles to the igneous bodies. The thickness of the zone of natural coke is usually of the same magnitude as the thickness of the igneous body, and dikes emplaced vertically through the coal beds affect small quantities of coal in comparison to sills that parallel the coal beds. The following analyses of coal and natural coke samples, collected in the New Rouse mine (New Rouse coal bed) by G. B. Richardson $(1910$, p. 435) adjacent to a 14-inch dike, illustrate the chemical effects of igneous intrusion:

Ultimate analyses of natural coke and coal from New Rouse mine, sec. so, $T$. 29 S., R. 65 W.

(Moisture and ash free basis. After Richardson)

\begin{tabular}{|c|c|c|c|}
\hline & $\begin{array}{l}\text { Natural coke } \\
1 \text { ft from dike }\end{array}$ & $\begin{array}{l}\text { Coal } 1 \mathrm{ft} \text { from } \\
\text { natural coke, } \\
21 / 2 \mathrm{ft} \text { from dike }\end{array}$ & $\begin{array}{l}\text { Coal } 15 \mathrm{ft} \\
\text { from dike }\end{array}$ \\
\hline \multirow[t]{2}{*}{$\begin{array}{l}\text { Hydrogen } \\
\text { Carbon } \\
\text { Nitrogen } \\
\text { Oxygen } \\
\text { Sulfur }\end{array}$} & $\begin{array}{r}2.82 \\
91.41 \\
1.21 \\
3.85 \\
.71\end{array}$ & $\begin{array}{r}5.70 \\
81.98 \\
1.32 \\
10.27 \\
.73\end{array}$ & $\begin{array}{r}5.60 \\
81.51 \\
1.42 \\
10.72 \\
.75\end{array}$ \\
\hline & 100.00 & 100.00 & 100.00 \\
\hline
\end{tabular}

Proximate analyses of natural coke from the Trinidad field show that few, if any, impurities were introduced by the intruding magmas, and that the percentage of ash and volatiles lies somewhere between that of coal and artificial coke. Although the natural coke is probably an excellent fuel, it is not mined because it is interlaced with stringers of igneous rocks that require sorting and increase mining difficulties.

The few analyses of coals in this area that are available show that the coal is bituminous in rank, and high volatile $A$ and $B$ in type. The following table consists of analyses selected from some of the coal beds in the area. 
COAL RESOURCES, TRINIDAD-AGUILAR AREA, COLORADO
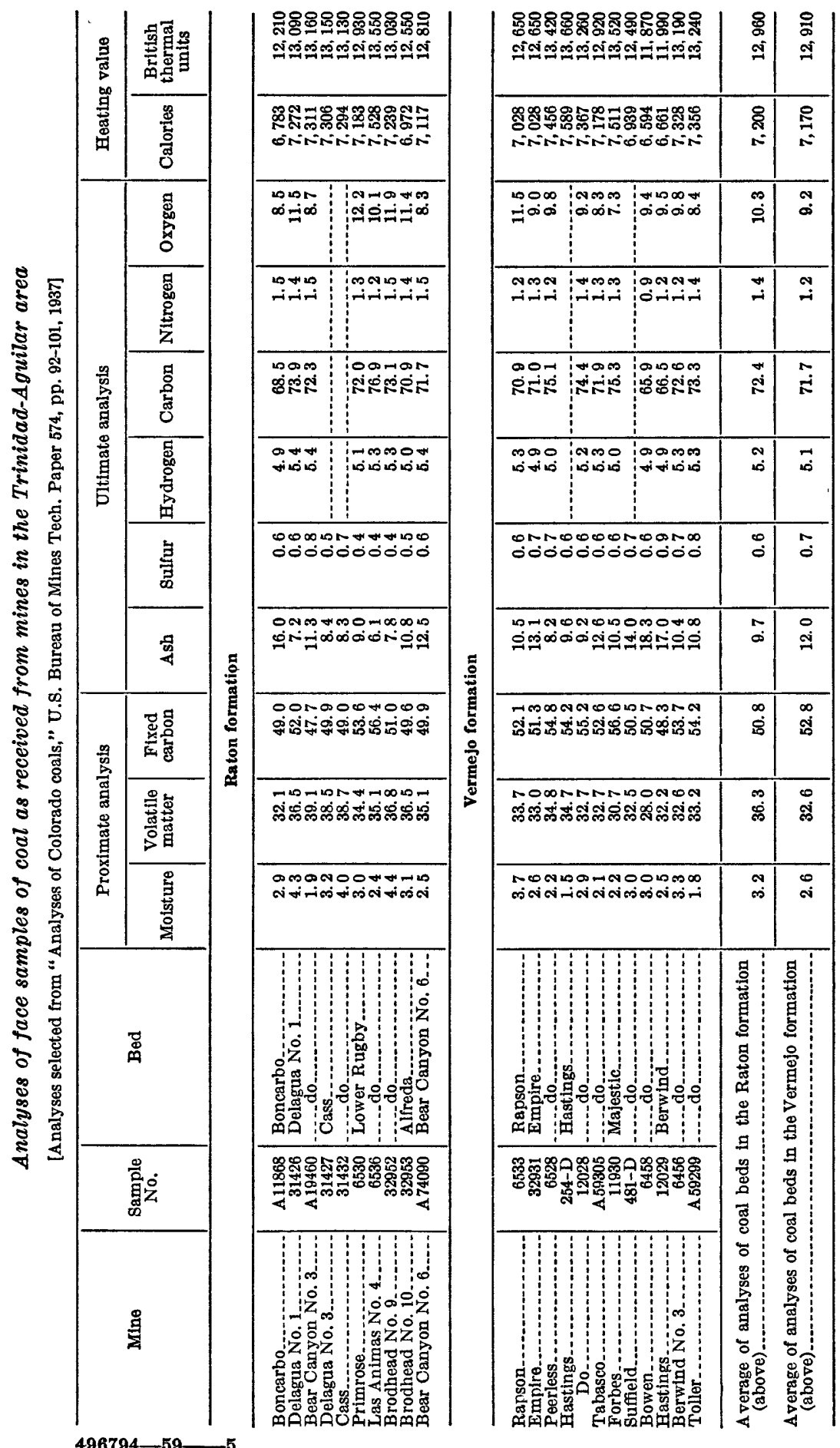
The Raton Mesa coal region, which includes the Raton and Trinidad coal fields, is the third largest western producer of coking coal. Many, if not most, of the coals in the Trinidad-Aguilar portion of the Trinidad field will coke. Coking coal becomes semiliquid and bubbly with gases of decomposition at high temperatures in reducing ovens. Upon cooling, the coke is a hard cellular mass of carbon and inert matter and is used as a fuel and reducing agent in the smelting of metals, notably iron. Blast-furnace coke must meet rigid standards of purity, strength, density, and piece size. The coke that is obtained from coal of the Trinidad and Raton fields (blended with small amounts of noncoking coal) is of superior metallurgical quality (Berryhill and Averitt, 1951, p. 14-15) and has long been used at steel mills in Pueblo, Colo.

The coking quality of the coals of the Trinidad field decreases northward, and coal in the Walsenburg and $\mathrm{La}$ Veta districts will not coke (Richardson, 1910, p. 443-445; Johnson and Stephens, 1954b). Coking coal generally contains slightly less oxygen than noncoking varieties, but the causes of the variation in oxygen content are not always known. In many western mining districts, coal that will coke is limited to aureoles surrounding igneous bodies, indicating that coal in these fields acquired coking properties by deoxidation resulting from heat. The coking ability of the coal in the Trinidad field, however, is apparently unrelated to metamorphism by heat or pressure. Coal that will not coke occurs in steeply folded beds adjacent to igneous intrusions (Johnson and Stephens, 1954b), and many of the coking coals of the Trinidad-Aguilar area are flat-lying and far from igneous intrusions. Recent investigation by V. H. Johnson (1952) suggests that the coking ability of coal near Paonia, Colo., is intimately related to ground water circulation and that coal above the regional water table in that field has lost its original coking properties through oxidation by alternate wetting and drying. If this should be true in the Trinidad field, coking ability of the coal would increase at depth and the bulk of the reserves, even in the northern part of the field, would consist of coking coal. A comprehensive study of the coking properties of the coals would require core-drilling because most of the mines are closed and fresh samples cannot be obtained.

\section{DEVELOPMENT}

The room-and-pillar method of coal mining is suited to this area because the beds are almost horizontal, and shafts or "rock tunnels" are not, in most cases, needed to reach unmined coal. Eventually, when the coal easy of access is depleted, shafts will be necessary to reach the beds in the interior of the field. Mining by stripping 
methods is impracticable because of the hilly topography in the coal field.

The coal of the Raton Mesa region, discovered in 1846 by Emory (1848, p. 19), was not mined until about 1873. The Trinidad field, of which this area is a part, developed rapidly because of the superior chemical and physical properties of the coal, and, in 1889, annual production reached 1 million short tons. The period of greatest coal production was from 1905 to 1927 and a high of nearly 8 million tons was produced in 1910. Annual production declined at the approach of the depression and with increased competition from other fuels, but, through 1951, had never fallen below 1 million tons. The total production of the Trinidad field (Las Animas and Huerfano Counties) through 1951 was 225 million tons (Spencer and Erwin, 1953, p. 12-13).

Coal production in the Trinidad-Aguilar area, through 1950, was $83,682,000$ short tons (see following table). Of this amount, 48,914,000 tons was produced from 50 mines in coal beds of the Vermejo formation, and 34,768,000 tons from 30 mines in the Raton formation. The exact location of many of these mines is unknown, and, for this reason, all the mines are not shown on the geologic map. It is impossible to break down the figures on a basis of individual coal beds because of duplication and changing of mine names, the shifting of mines from one bed to another, and the simultaneous mining of closely spaced beds. Two important mines that simultaneously exploited more than one coal bed were the Delagua and Ludlow mines.

Much of the coal formerly produced in the Trinidad field was treated in beehive ovens near the tipples and shipped to industrial centers as coke. This practice has been abandoned because of the wastage of heat and volatiles, and the coking is now done at industrial centers where the process is carefully controlled and important byproducts are obtained.

Mining activity in the area has slackened in recent years, and large mines at Delagua, Boncarbo, and Ludlow have been forced to close. Mines were operating at Bear Canyon, Rapson, Baldy, Gem, Franklin, Leader, and New Rugby in 1953. Most of these mines operate seasonally because the production is largely for local domestic use. The Bear Canyon and Rapson mines are served by the only remaining railroad branch lines in the area.

Present mining methods are affected by the recent decrease in demand for coal. The deeper parts of most of the mines have been abandoned and production is mostly from blocks of coal closer to the entries that were overlooked or held in reserve during earlier operations. Colorado Fuel and Iron Corporation, which formerly operated 


\section{Coal production through 1950 in the Trinidad-Aguilar area}

[Production figures, in thousands of short tons, compiled from annual reports of the Colorado Mine Inspector]

\begin{tabular}{|c|c|c|c|c|c|c|}
\hline \multirow{2}{*}{ Mine } & \multicolumn{3}{|c|}{ Location cf entry } & \multirow{2}{*}{$\begin{array}{c}\text { Years } \\
\text { operated }\end{array}$} & \multirow{2}{*}{ Coal bed } & \multirow{2}{*}{$\begin{array}{c}\text { Produc- } \\
\text { tion }\end{array}$} \\
\hline & $\begin{array}{l}\text { Town- } \\
\text { ship } \\
\text { (S.) }\end{array}$ & $\underset{\text { (W.) }}{\text { Range }}$ & Section & & & \\
\hline
\end{tabular}

Raton formation

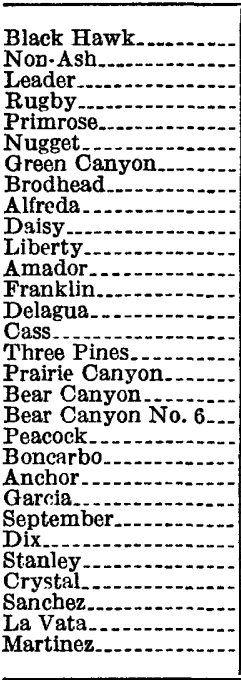

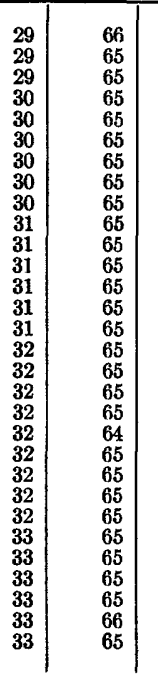

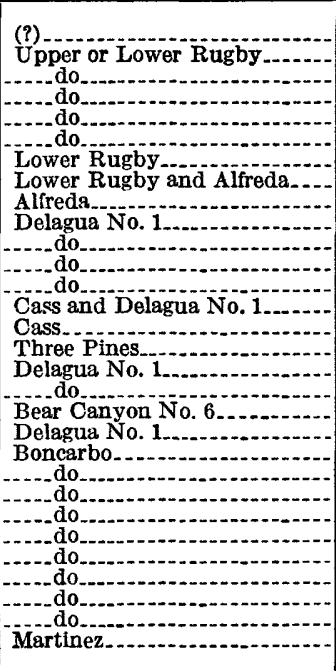

73
5
205
1,235
1,145
15
489
3,611
1
54
24
15
24
15,910
551
248
197
453
1,092
13
4,430
3,691
12
3
1,116
110
8
7
28
3

Vermejo formation

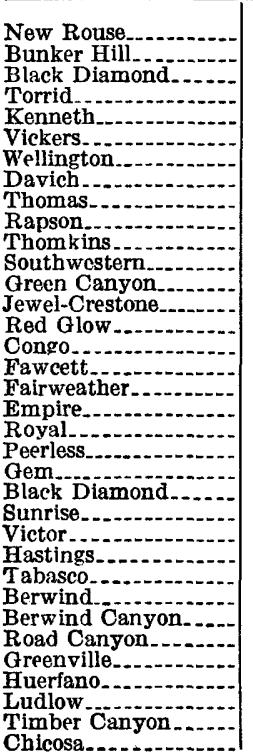

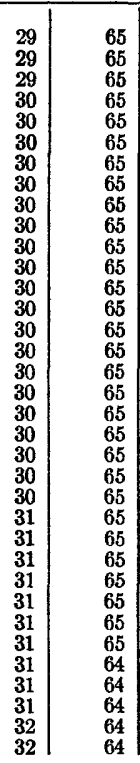

\begin{tabular}{c|r|}
30 & $1899-1920$ \\
29 & $1898-1936$ \\
32,33 & $1901-22$ \\
5 & $1925-37$ \\
5 & $1909-49$ \\
$5 ?$ & $1923-26$ \\
4 & $1924-28$ \\
4 & $1929-31$ \\
4 & $1907-09$ \\
9 & $1900-50$ \\
9 & $1914-29$ \\
16 & $1903-27$ \\
16 & $1939-50$ \\
$16 ?$ & $1901-50$ \\
21 & $1948-50$ \\
$21 ?$ & $1911-31$ \\
22 & $1923-29$ \\
21 & $1949-50$ \\
28 & $1907-35$ \\
28 & $1911-30$ \\
27 & $1892-1913$ \\
34 & $1932-50$ \\
35 & $1936-48$ \\
1 & $1935-50$ \\
$13 ?$ & $1891-98$ \\
13,24 & $1899-1923$ \\
25 & $1901-30$ \\
36 & $1892-1928$ \\
$36 ?$ & $1939-50$ \\
$36 ?$ & 1891 \\
30 & $1903-27$ \\
32 & $1905-12$ \\
32 & $1903-50$ \\
5 & $1931-32$ \\
$8 ?$ & $1891-92$
\end{tabular}

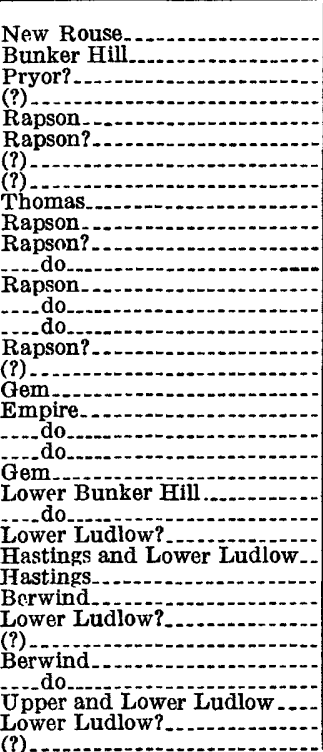


Coal production through 1950 in the Trintilad-Aguttor area-Continued

\begin{tabular}{|c|c|c|c|c|c|c|}
\hline \multirow{2}{*}{ Mine } & \multicolumn{3}{|c|}{ Loeation of entry } & \multirow{2}{*}{$\begin{array}{c}\text { Years } \\
\text { operated }\end{array}$} & \multirow{2}{*}{ Coal bed } & \multirow{2}{*}{$\begin{array}{c}\text { Produc- } \\
\text { tion }\end{array}$} \\
\hline & $\begin{array}{l}\text { Town- } \\
\text { ship } \\
\text { (S.) }\end{array}$ & $\begin{array}{c}\text { Range } \\
(\bar{W} .)\end{array}$ & Bection & & & \\
\hline \multicolumn{7}{|c|}{ Vermejo formation-Continued } \\
\hline 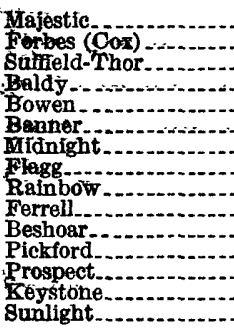 & $\begin{array}{l}\mathbf{3 2} \\
\mathbf{3 2} \\
\mathbf{3 2} \\
\mathbf{3 2} \\
\mathbf{3 2} \\
\mathbf{3 2} \\
\mathbf{3 2} \\
\mathbf{3 2} \\
\mathbf{3 2} \\
\mathbf{3 2} \\
\mathbf{3 3} \\
\mathbf{3 3} \\
\mathbf{3 3} \\
\mathbf{3 3} \\
\mathbf{3 3}\end{array}$ & $\begin{array}{l}64 \\
64 \\
64 \\
64 \\
64 \\
64 \\
64 \\
64 \\
64 \\
64 \\
64 \\
64 \\
64 \\
64 \\
64\end{array}$ & $\begin{array}{r}9 \\
10,15,16 \\
13,14 \\
.28 \\
24 \\
24 ? \\
25 \\
26 \\
27 \\
27 ? \\
11 \\
11 \\
10 \\
10 \\
10\end{array}$ & $\begin{array}{r}1900-14 \\
1899-1050 \\
1904-48 \\
1905-50 \\
1899-19442 \\
1925-27 \\
1934-37 \\
1928-36 \\
1934-41 \\
1914-32 \\
1917-37 \\
1918-34 \\
1913-41 \\
1915-18 \\
1905-28\end{array}$ & 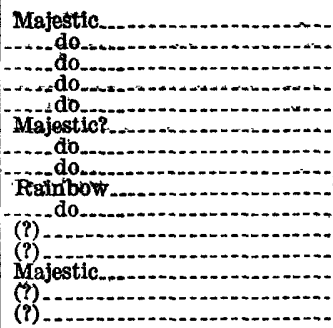 & $\begin{array}{r}1,848 \\
2,800 \\
1,945 \\
261 \\
2,723 \\
8 \\
5 \\
2 \\
3 \\
4 \\
24 \\
15 \\
47 \\
7 \\
4\end{array}$ \\
\hline Total. & - & - - & & $\ldots$ & & $\ldots . .83,682$ \\
\hline
\end{tabular}

many mines in the area and consumed much of the coal produced in other mines, has recently opened the Allen mine in the upper valley of Purgatoire River.

Despite a recent shump in the coal market, prospecting in the coal field continues. Many of the residents of the area formerly worked in the mines and retain their interest in coal mining.

Several factors indicate that closely spaced drill holes should be used to prospect the coal beds of the Trinidad field. As in most of the western conl fields, the beds are irregular in thickness, and the quality of the coal varies within individual beds. Moreover, much of the coal in the Trinidad field has been coked by intrusive bodies and rendered useless commercially.

Some of the cost-increasing factors in mines in the area include poor roofing material, uneven floors, and water seepage in deep parts of the mines. Gas has been reported in a few of the mines in the area.

The Trinidad-Aguilar area offers many advantages to the coal mining industry. These advantages include proximity to railroads, availability of timber and underground water, and the mild climate, which permits aboveground operation throughout the year. Large bodies of bituminous coal, much of it coking coal, remain untouched in beds of practicable mining thicknesses.

\section{RESERVES}

A total of $2,917,892,000$ short tons of coal (including natural coke) in beds more than 14 inches thick are estimated to remain in the Trinidad-Aguilar area. The coal is all of bituminous rank and of high volatile $A$ and $B$ types. No satisfactory means of determining 
the amount of coal coked by igneous intrusion exists. Approximately 10 percent of the coal is coked at the surface of the area, but this percentage probably increases westward toward the intrusive centers of the Spanish Peaks in the interior of the Raton basin.

The total remaining reserves were estimated by subtracting the estimated depletion $(167,364,000$ tons) from the estimated total original reserves $(3,085,256,000$ tons). The total original reserves were estimated by assuming that the coal-bearing rocks contain as much coal at depth as at the outcrop (zone analysis). The depletion was estimated by doubling the production tonnage (page 477) as a result of the observation that as much coal is usually left in the ground or otherwise lost in mining operations as is produced (Spencer and Erwin, 1953, p. 2).

Total estimated original coal reserves, in thousands of short tons, in the TrinidadAguilar area

Ts. 29 and 30 S., R. 65 W._. 406,453

Ts. 29 and 30 S., R. 66 W.

T. 31 S., Rs. 64 and $65 \mathrm{~W}$

T. 31 S., R. 66 W

T. 32 S., R. 64 W.

T. 32 S., R. 65 W...

T. 32 S., R. 66 W W

T. 33 S, R. 64 W

T. 33 S., Rs. 65 and 66 W.

Total...... $3,085,256$

The reserves in the preceding table include coal in beds that do not crop out, but are assumed by statistical analysis to underlie the interior of the coal field. The following table shows the estimated original reserves in the beds which crop out in the area. These reserves are classified according to thickness and amount of overburden. Partings thicker than three-eighths of an inch were excluded from the thickness of the beds, and the coal was assumed to weigh 1,800 tons per acre foot. The reserves of these beds are further classified into measured, indicated, and inferred categories. These categories are limited arbitrarily ; the measured and indicated category in this report includes coal within half a mile of the point of observation, and the inferred category includes coal beyond that limit. 
COAL RESOURCES, TRINIDAD-AGUILAR AREA, COLORADO

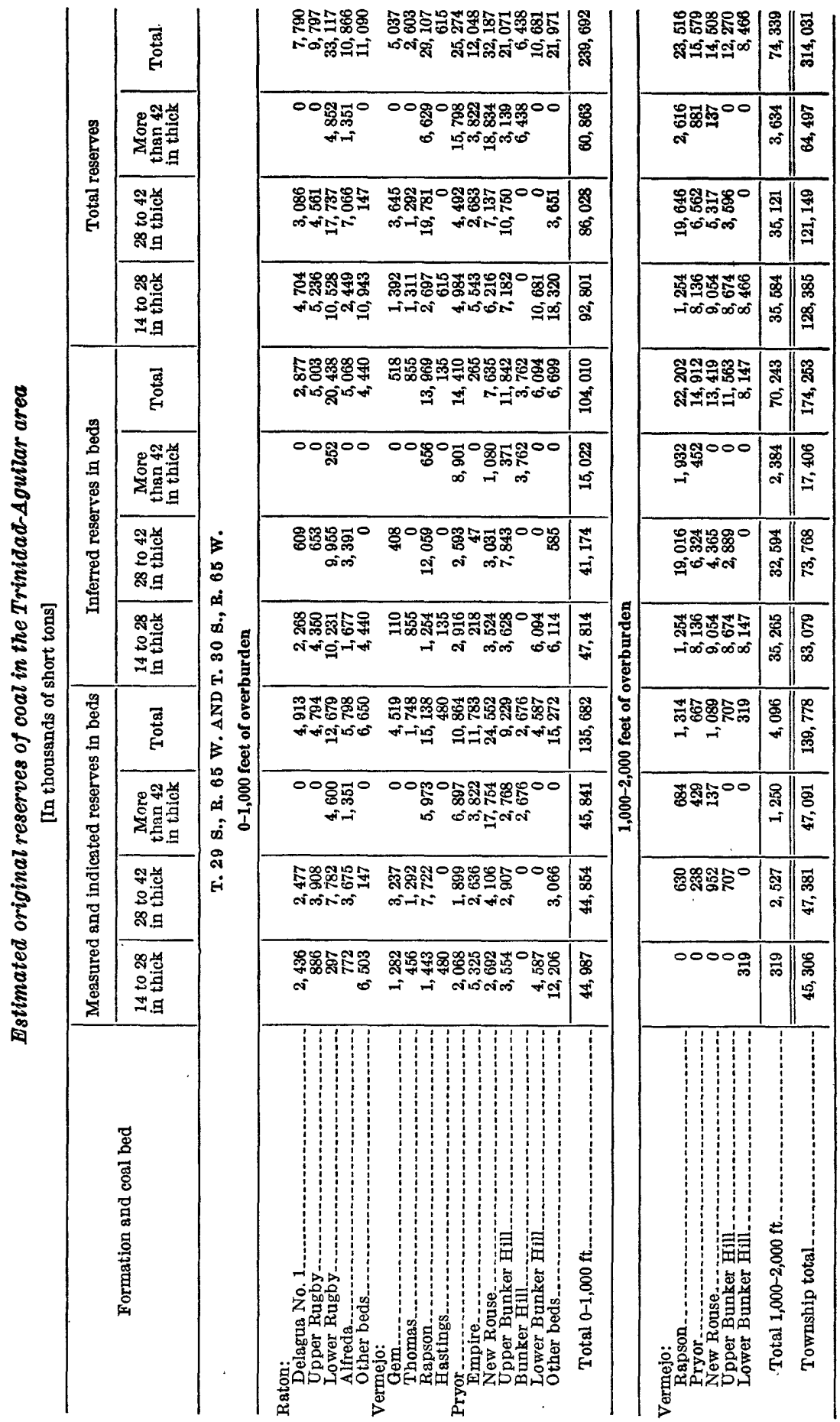




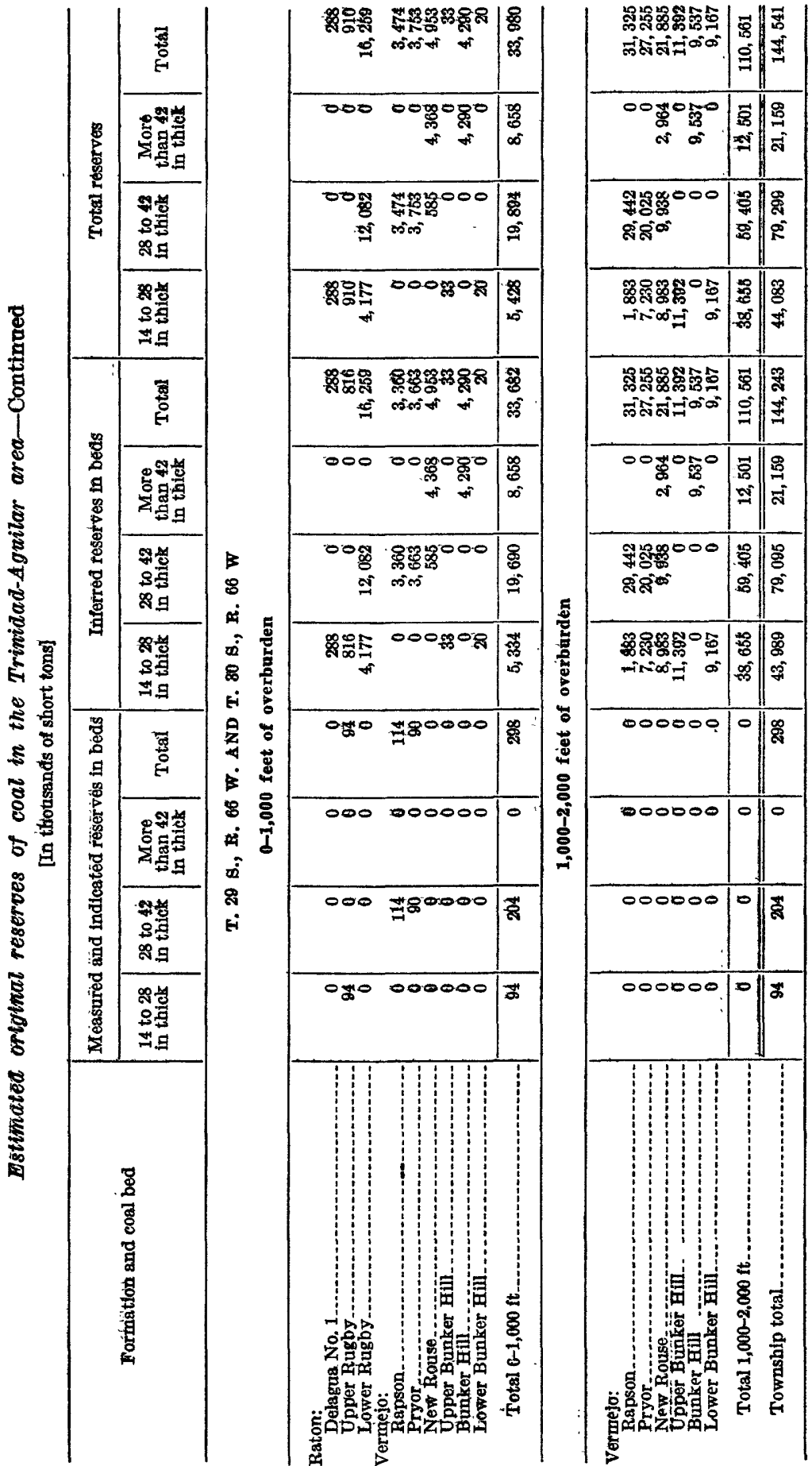




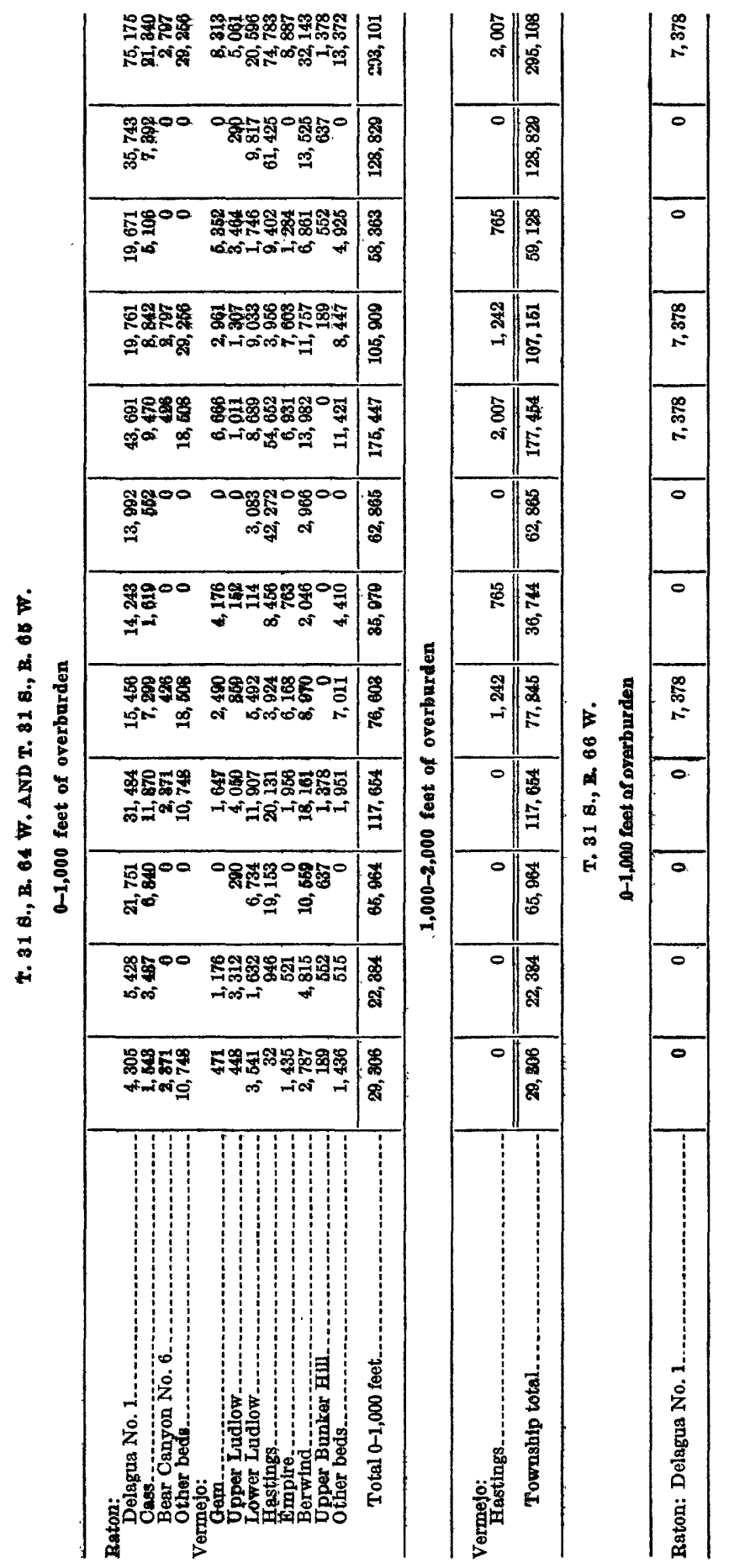



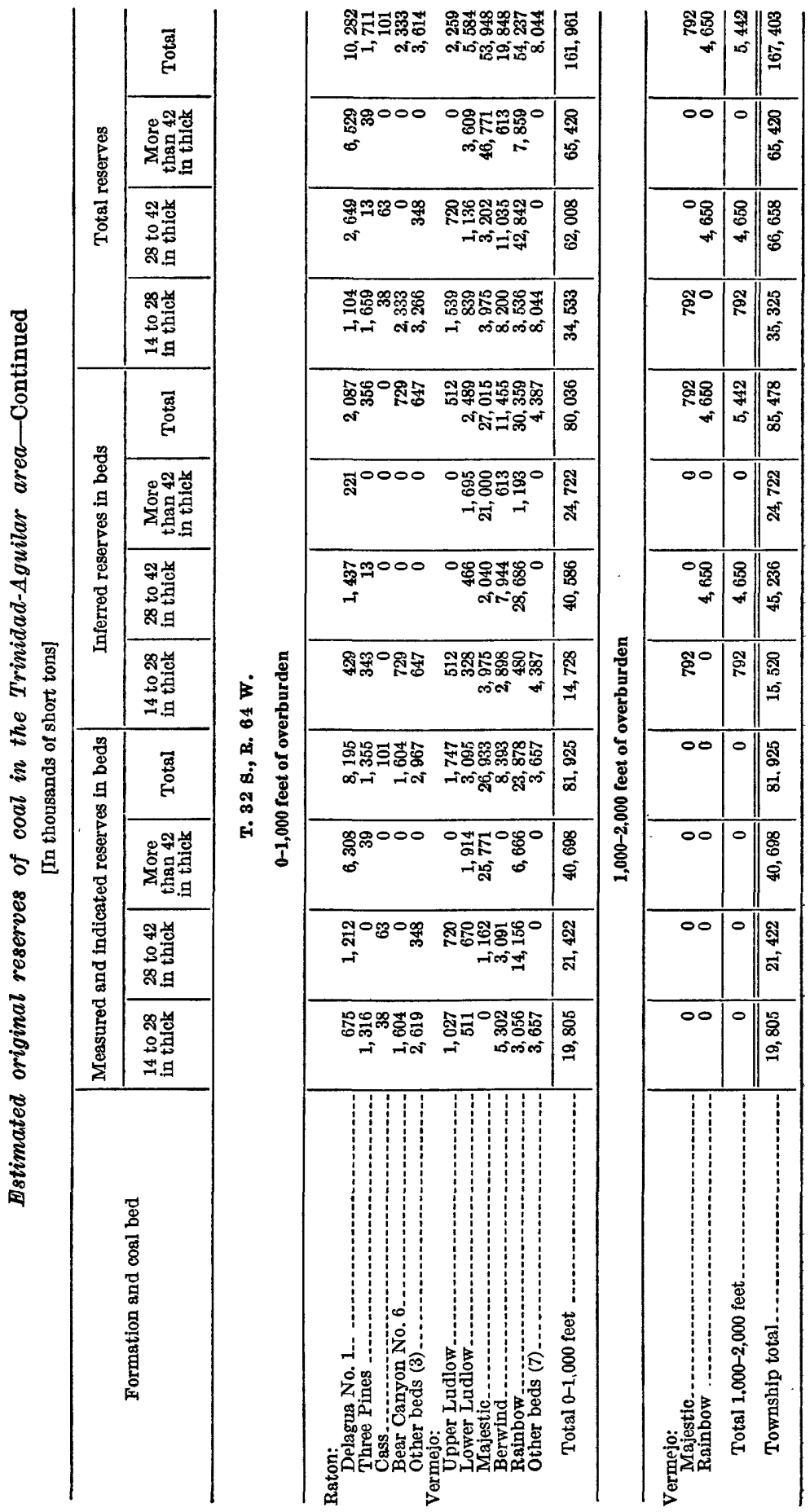
COAL RESOURCES, TRINIDAD-AGUILAR AREA, COLORADO

483

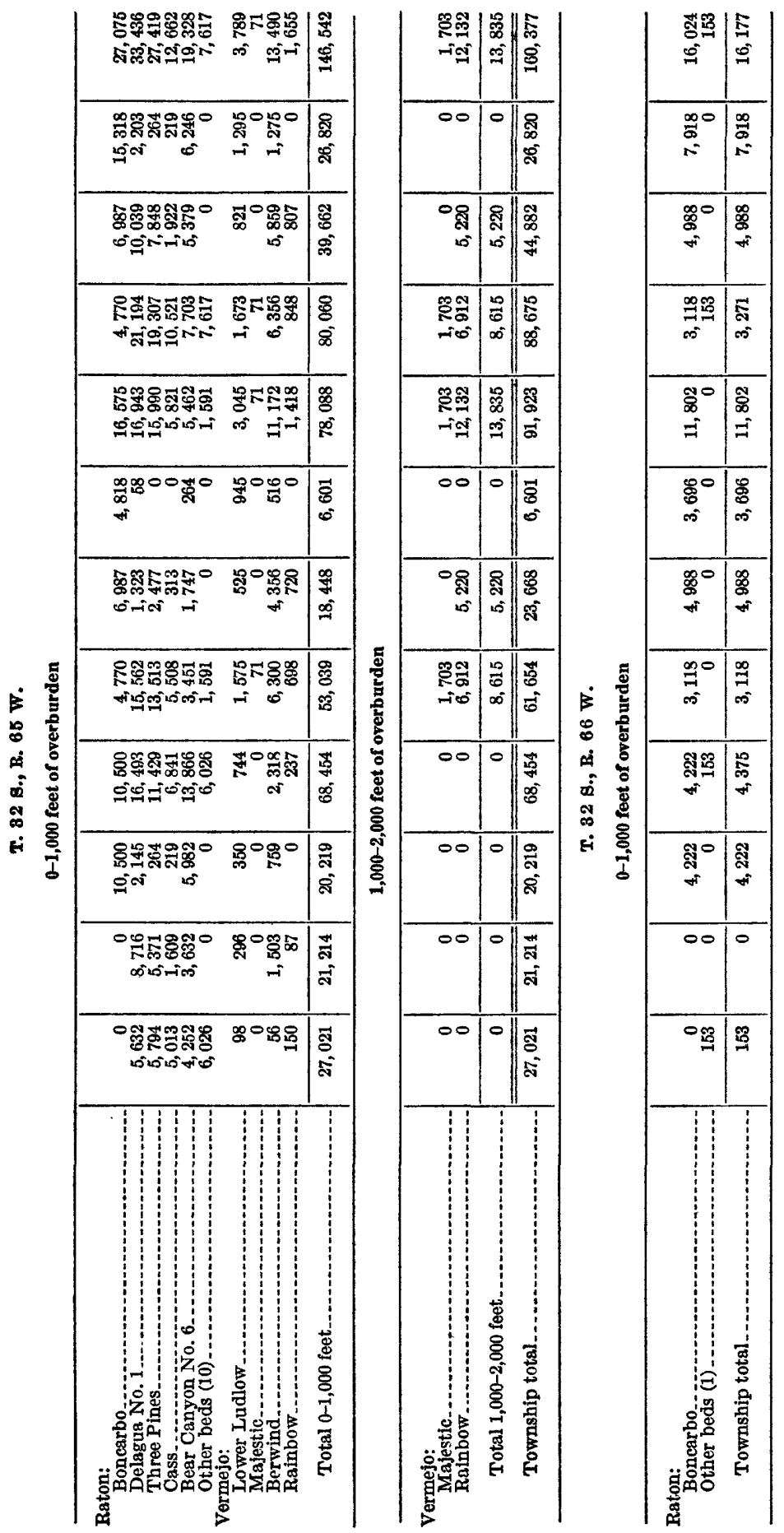




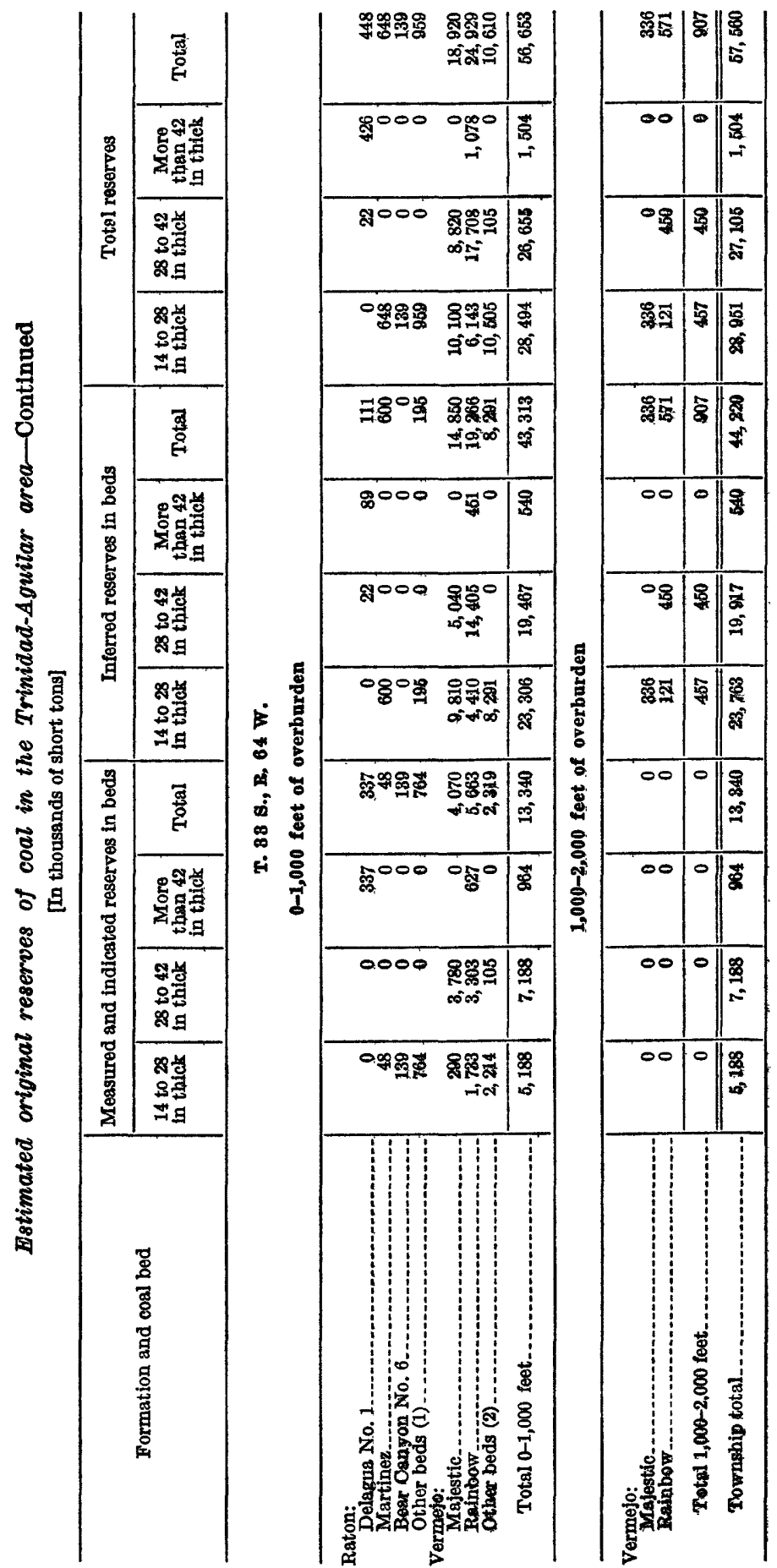


COAL RESOURCES, TRINIDAD-AGUILAR AREA, COLORADO

485

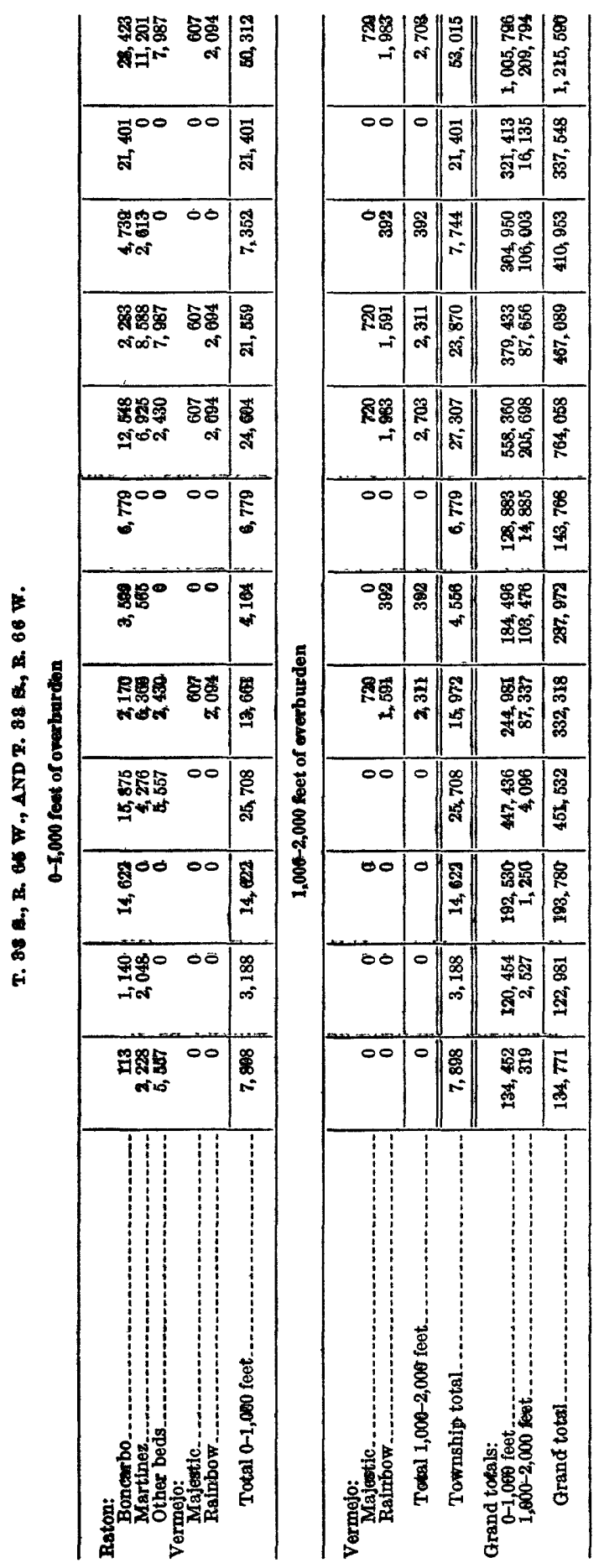




\section{REFERENCES}

Abert, J. W., 1848, Report on the examination of New Mexico in the year 18461847 : Rept. Secretary War, U.S. 30th Cong., 1st sess., S. Ex. Doc. 23, p. 3-130; H. Ex. Doc. 41, p. 417-546.

Bachman, G. O., 1953, Geology of a portion of northwestern Mora County, N. Mex.: U.S. Geol. Survey Oil and Gas Inv. Map OM 137.

Bailey, J. W., 1848, Notes concerning the minerals and fossils collected by Lt. J. W. Abert while engaged in the geographical examination of New Mexico: Rept. Secretary War, U.S. 30th Cong., 1st sess., S. Ex. Doc. 23, p. 131-132; H. Ex. Doc. 41, p. 547-548.

Bass, N W., 1947, Structure contour map of the surface rocks of the Model anticline, Las Animas County, Colo.: U.S. Geol. Survey Oil and Gas Inv. Prelim. Map 68.

Berryhill, L. R., and Averitt, Paul, 1951, Coking coal deposits of the western United States: U.S. Geol. Survey Circ. 90, 20 p.

Brown, R. W., 1943, Cretaceous-Tertiary boundary in the Denver basin, Colorado: Geol. Soc. America Bull., v. 54, p. 65-86.

Conkling, A. R., 1877, Report on the foothills facing the plains from latitude $35^{\circ} 30^{\prime}$ to $38^{\circ}$ approximately : U.S. Geog. Surveys W. 100th Mer. Rept.

Dane, C. H., Pierce, W. G., and Reeside, J. B., Jr., 1937, The stratigraphy of the Upper Cretaceous rocks north of the Arkansas River in eastern Colorado: U.S. Geol. Survey Prof. Paper 186-K, p. 207-232.

Emory, W. H., 1848, Notes on a military reconnaissance from Fort Leavenworth, in Missouri, to San Diego, in California, including parts of the Arkansas, Del Norte, and Gila Rivers: U.S. 30th Cong., 1st sess., S. Ex. Doc. 7, p. 5-126; H. Ex. Doc. 41 , p. 5-126.

Endlich, F. M., 1877, Report as geologist of the southeastern division : U.S. Geol. and Geog. Survey Terr. 9th Ann. Rept., p. 103-235.

Gilbert, G. K., 1896, The underground water of the Arkansas Valley in eastern Colorado: U.S. Geol. Survey 17th Ann. Rept., pt. 2, p. 551-601.

Harbour, R. L., and Dixon, G. H., 1956, Geology of the Trinidad-Aguilar area, Las Animas and Huerfano Counties, Colo.: U.S. Geol. Survey Oil and Gas Inv. Map OM 174.

Hayden, F. V., 1867, First annual report of the United States Geographical and Geological Survey of the Territories, embracing Nebraska: $64 \mathrm{p}$.

- 1868a, Rocky Mountain coal beds : Am. Jour. Sci., 2d ser., v. 45, p. 101-102. 1868b, Notes on the lignite deposits of the West: Am. Jour. Sci., 2d ser., v. 45, p. 198-208.

1873, Geological report: U.S. Geol. and Geog. Survey Terr. 1st, 2d, and 3d Ann. Repts., p. 103-199.

- 1874, General report: U.S. Geol. and Geog. Survey Terr. 7th Ann. Rept., p. 17-82.

1876, General report: U.S. Geol. and Geog. Survey Terr. 8th Ann. Rept., p. $19-58$.

- 1876, Notes on the lignitic group of eastern Colorado and portions of Wyoming: U.S. Geol. and Geog. Survey Terr. Bull., v. 1, 2d ser., no. 5, p. $401-411$.

Hills, R. C., 1899, Description of the Elmoro quadrangle, Colorado: U.S. Geol. Survey Geol. Atlas, Folio 58, 6 p.

1900, Description of the Walsenburg quadrangle, Colorado: U.S. Geol. Survey Geol. Atlas, Folio 68, 6 p. 
Hills, R. C., 1901, Description of the Spanish Peaks quadrangle, Colorado: U.S. Geol. Survey Geol. Atlas, Folio 71, 7 p.

James, Edwin, 1821, Geological sketches of the Mississippi Valley: Acad. Nat. Scl. Philadelphia Jour., v. 2, p. 326-329.

Johnson, R. B., 1958, Geology and coal resources of the Walsenburg area, Huerfano County, Colo.: U.S. Geol. Survey Bull. 1042-0, p. 557-583.

- 1959, Geology of the Huerfano Park area, Huerfano and Custer Counties, Colo.: U.S. Geol. Survey Bull. 1071-D, pp. 87-120.

Johnson, R. B., and Stephens, J. G., 1954a, Geology of the La Veta area, Huerfano County, Colo.: U.S. Geol. Survey Oil and Gas Inv. Map OM 146.

Johnson, R. B., and Stephens, J. G., 1954b, Coal resources of the La Veta area, Huerfano County, Colo.: U.S. Geol. Survey Coal Inv. Map C 20.

1955, Geologic map of the Walsenburg area, Huerfano County, Colo.: U.S. Geol. Survey Oil and Gas Inv. Map OM 161.

Johnson, V. H., 1952, Thermal metamorphism and ground water alteration of coking coal near Paonia, Colo.: Mining Engineering, v. 4, no. 4, p. 391-395; Am. Inst. Mining Metall. Eng. Trans., v. 193, p. 391-395.

Knopf, Adolph, 1936, Igneous geology of the Spanish Peaks region, Colorado: Geol. Soc. America Bull., v. 47, p. 1727-1784.

Lavington, C. S., 1933, Montana group in eastern Colorado: Am. Assoc. Petroleum Geologists Bull., v. 17, p. 397-410.

Le Conte, J. L., 1868, Notes on the geology of the survey for the extension of the Union Pacific Railway from Smoky Hill River, Kans., to the Rio Grande: Philadelphia, 76 p.

Lee, W. T., 1909, Unconformity in the so-called Laramie of the Raton coal field, New Mexico: Geol. Soc. America Bull., v. 20, p. 357-368.

1911, Further evidence of an unconformity in the so-called Laramie of the Raton coal field, New Mexico (abstract) : Geol. Soc. America Bull., v. 22, p. 717.

1913, Recent discoveries of dinosaurs in the Tertiary: Am. Jour. Sci., 4th ser., v. 35, p. 531-534.

1916, Relation of the Cretaceous formations of the Rocky Mountains in Colorado and New Mexico: U.S. Geol. Survey Prof. Paper 95-C, p. 27-58.

Lee, W. T., 1922, Description of the Raton, Brilliant, and Koehler quadrangles, New Mexico-Colorado: U.S. Geol. Survey Geol. Atlas, Folio 214, 17 p.

1924, Coal resources of the Raton coal field, Colfax County, N. Mex. : U.S. Geol. Survey Bull. 752.

Lee, W. T., and Knowlton, F. H., 1917, Geology and paleontology of the Raton Mesa and other regions in Colorado and New Mexico: U.S. Geol. Survey Prof. Paper 101.

Lesquereux, Leo, 1872a, An enumeration with description of some Tertiary fossil plants from specimens procured in the exploration of Dr. F. V. Hayden in 1870 : U.S. Geol. and Geog. Survey Terr., 5th Ann. Rept., p. 1-22.

$1872 \mathrm{~b}$, Tertiary flora of North America: U.S. Geol. and Geog. Survey Terr. 5th Ann. Rept., p. 304-318.

1873, Lignitic formations and fossil flora: U.S. Geol. and Geog. Survey Terr. 6th Ann. Rept., p. 317-427.

1874 , On the formation of the lignite beds of the Rocky Mountain region: Am. Jour. Sci., 3d ser., v. 7, p. 29-31, 546-557.

1878, The Tertiary flora: U.S. Geol. and Geog. Survey Terr. Rept., v. 7, p. 1-366. 
Lesquereux, Leo, 1883, Contributions to the fossil flora of the western territories; pt. 3, The Cretaceous and Tertiary flora: U.S. Geol. and Geog. Survey Terr. 10th Ann. Rept., v. 8, 283 p.

Long, S. H., 1823, Account of an expedition from Pittsburg to Rocky Mountains, performed in the years 1819-20 (compiled by Edward James) : v. 1, 503 p., v. $2,442 \mathrm{p}$.

McLaughlin, T. G., 1954, Geology and water resources of Baca County, Colo.: U.S. Geol. Survey Water-Supply Paper 1256, 232 p. [1955].

Newberry, J. S., 1874, On the lignites and plant beds of western America : Am. Jour. Sci., 3d ser., v. 7, p. 399-404.

Owen, R. E., and Cox, E. T., 1865, Report on the mines of New Mexico, $60 \mathrm{p}$. (abstract) : Am. Jour. Sci., 2d ser., v. 40, p. 391-392.

Read, C. B., and Wood, G. H., Jr., 1947, Distribution and correlation of Pennsylvanian rocks in late Paleozoic sedimentary basins of northern New Mexico: Jour. Geology, v. 55, p. 220-236.

Richardson, G. B., 1910, The Trinidad coal field, Colorado, in Coal fields in Colorado and New Mexico: U.S. Geol. Survey Bull. 381-C, p. 379-446.

St. John, O. H., 1876, Notes on the geology of northeastern New Mexico: U.S. Geol. and Geog. Survey Terr. Bull., v. 2, p. 279-308.

Spencer, F. D., and Erwin, M. I., 1953, Coal resources of Colorado: U.S. Geol. Survey Circ. 258, $17 \mathrm{p}$.

Stevenson, J. J., 1879, Report on a special geological party operating in Colorado and New Mexico from Spanish Peaks to the south, field season of 1878: U.S. Geog. Surveys W. 100th Mer. Ann. Rept.

- 1881, Report upon geological examinations in southern Colorado and northern New Mexico during the year 1878 and 1879: U.S. Geog. Surveys W. 100th Mer. Rept., v. 3, 420 p.

Stevenson, J. J., 1889, The Mesozoic rocks of southern Colorado and northern New Mexico: Am. Geologist, v. 3, p. 391-397.

Waagẽ, K. M., 1955, Dakota group in the northern Front Range foothills, Colorado: U.S. Geol. Survey Prof. Paper 274-B, p. 15-51.

Wood, G. H., Jr., Johnson, R. B., and others, 1951, Geology and coal resources of the Stonewall-Tercio area, Las Animas County, Colo.: U.S. Geol. Survey Coal Inv. Map $\mathbf{C} 4$.

Wood, G. H., Jr., Northrop, S. A., and Griggs, R. L., 1953, Geology and stratigraphy of Koehler and Mount Laughlin quadrangles and parts of Abbot and Springer quadrangles, eastern Colfax County, N. Mex.: U.S. Geol. Survey Oil and Gas Inv. Map OM-141.

Wood, G. H., Jr., Johnson, R. B., and Dixon, G. H., 1956, Geology and coal resources of the Gulnare, Cuchara Pass, and Stonewall area, Huerfano and Las Animas Counties, Colo. : U.S. Geol. Survey Coal Inv. Map O-26.. 1957, Geology and coal resources of the Starkville-Weston area, Las Animas County, Colo.: U.S. Geol. Survey Bull. 1051. 


\section{INDEX}

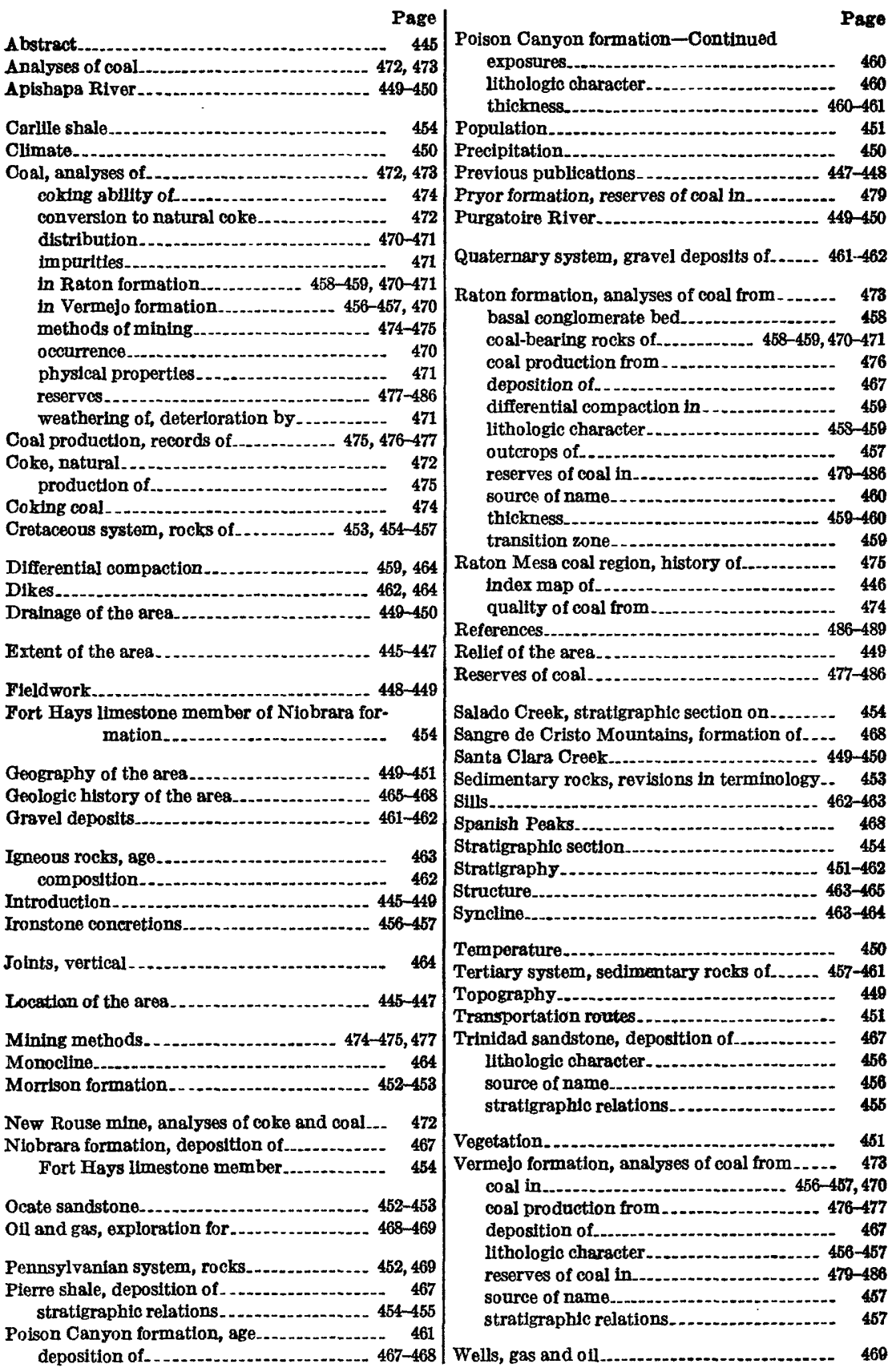




